\title{
Vicdan ve Akıl Kıskacında İnsanlık, Komşuluk, Kardeşlik: Suriyeli Sığınmacılara İlişkin Algılara Politika Pazarlaması Perspektifinden Bir Bakış
}

\begin{abstract}
Elif Boyraz ${ }^{1}$
Hatice Sözüpek ${ }^{2}$

Sabriye Esen ${ }^{3}$

Okan $\mathrm{Ay}^{4}$

Vicdan ve Akıl Kıskacında İnsanlık, Komşuluk, Kardeşlik: Suriyeli Sığınmacılara İlişkin Algılara Politika Pazarlaması Perspektifinden Bir Bakış

Öz

Bu araştırmanın amacı Suriyeli göçmenlerin ikamet ettikleri bölgelerde, yerel halkın birlikte yaşamaya ilişkin algılarını ve göçmenlere karşı tutumlarını belirlemektir. Bu amaç doğrultusunda çok sayıda Suriyeli göçmenin ikamet ettiği üç ilde (Mardin, İstanbul, Tokat) 400 katılımcıya yüzyüze anket uygulanmıştır. Elde edilen veriler SPSS paket programı yardımıyla analiz edilmiştir. Araştırma bulguları yerli halkın göçmenlere ilişkin algılarının akıl ve vicdan arasında sıkıştığını ve bu nedenle değişkenlik gösterdiğini ortaya koymaktadır. Yerli halk göçmenlerin getirdiği ekonomik yükten dolayı endişe duymakta, onlara sunulan sosyal imkânların yerli halkı ekonomik anlamda zor duruma soktuğunu düşünmekte; buna karşılık, savaştan kaçan komşu ülke vatandaşlarına kapıları açmanın komşu-

Humanity, Neighbourhood, Brotherhood between the Clip of Conscience and Mind: A View on the Perceptions about the Syrian Refugees from the Perspective of Marketing the Politics

Abstract

The purpose of this study is to identify the citizens' perceptions and attitudes about living with Syrian refugees. In accordance with this purpose a questionnaire was applied to 400 participants in three cities (Mardin, Istanbul, Tokat) that have a big refugee population. The data was analysed by SPSS packet program. The findings show that the perceptions are clipped between mind and conscience and so can differ in different situations. The citizens worry about the economic results of refugee politics and the social aids that are supplied to refugees. However they think helping the neighbour country's citizens that are running away the war is not only the neighbourhood and religion brotherhood responsibility, that is also the requirement of humanity.
\end{abstract} luk ve din kardeşliğinin daha da ötesi insanlığın bir gereği olduğunu düşünmektedir.

Anahtar Kelimeler: Göçmenler, Suriyeli Sığınmacılar, Sığınmacılar, Politika Pazarlaması
Keywords: Immigrant/Refugee/Asylum Seeker, Syrian Immigrants/Refugees, Marketing Politics

\section{Giriş}

Tarih boyunca yaşanan bireysel ya da kitlesel göçler, dünya nüfusunun coğrafik dağılımını; toplumların sosyal, kültürel, ekonomik ve politik yapılarını etkilemiş ve değişime uğratmıştır. İnsanoğlu tarih boyunca zorlu doğa koşullarından emin olmak, baskılardan kurtulmak, daha güvenli yerlerde yaşamak ve daha insani sosyal ortamlar yaratmak için göç edip durmuştur (Ünal, 2014: 66). İçişleri Bakanlığı Göç İdaresi Genel Müdürlüğü’nün tanımına göre göç; dini, ekonomik, sosyal ve diğer sebeplerden insan topluluklarının hayatlarının tamamını ya da bir kısmını geçirmek üzere yaşadıkları yerden başka bir yere yerleşerek yaptıkları coğrafi yer değişikliğidir

\footnotetext{
${ }^{1}$ Dr. Öğr. Üyesi, Gaziosmanpaşa Üniversitesi, iiBF, İşletme Bölümü, elifboyraz1@gmail.com, https://orcid.org/00000003-4717-1678

${ }^{2}$ haticesozupek66@gmail.com, https://orcid.org/0000-0002-4090-0666

${ }^{3}$ sabriyeesen4721@gmail.com, https://orcid.org/0000-0002-3632-5400

${ }^{4}$ okanay06@gmail.com, https://orcid.org/0000-0002-0705-260X
} 
(akt. Şanlıöz, 2016: 140). Mültecilik ve sığınmacılık zorunlu göç kategorisinde değerlendirilen; insanların, çeşitli baskılar görmeleri nedeniyle ülkelerini terk etmek zorunda kaldıkları bir olgudur (Yıldız, Ünlü ve Sezer, 2014: 42). Zorunlu göç bu yönüyle sosyal veya ekonomik nedenlerle gerçekleştirilen iradi göçten başka sonuçlar doğuran sosyolojik bir olgudur ve sebep olduğu sonuçların irdelenmesi, göç edenle göç ettiği yerin yerleşikleri arasındaki birlikte yaşama kültürünün oluşmasında oldukça önemlidir.

Dış göç olgusunun etkisi 2011'de Tunus'ta başlayan Arap Devrimleri ile birlikte artmaya başlamıştır. Arap Baharı olarak adlandırılan toplumsal hareketlerin Suriye'ye sıçraması bir iç savaşın başlamasına neden olmuş; çatışmalar uzayıp şiddetlendikçe canını kurtarmak için komşu ülkelerin sınırlarına yığılan insan toplulukları oluşmaya başlamıştır (Kaypak ve Bimay, 2016: 85). Suriye'deki hareketlilik 2011 yılının Mart ayında rejime karşı eylemler olarak başlayan sokak gösterileri sonrasında sürekli bir iç savaş halini almış, küresel güçlerin müdahalesiyle yüzbinlerce insanın ölümü ve yaralanması ile sonuçlanan büyük bir insani trajediye dönüşmüştür (Deniz, Hülür ve Ekinci, 2016: 1077). Bu trajedi, Suriye halkının hayatta kalma telaşıyla komşu ülkelerin sınırlarına akın etmesi sonucunu doğurmuştur. Bu kitlesel zorunlu göç hareketinden en güvenli görülen sınır ülke olarak Türkiye de nasibini almış ve mağdur Suriye halkına kapılarını açmıştır.

Coğrafik ve stratejik konumu nedeniyle Türkiye, istikrarsızlık ve insan hakları ihlalinin en sık yaşandığı Ortadoğu ve Asya ülkeleri ile refah düzeyi ve insan hakları standartları açısından sorunsuz Avrupa ülkeleri arasında bir köprü işlevi görmekte ve bu durum göç akımları için bir güzergah/koridor haline gelmesine sebep olmaktadır (Kaypak ve Bimay, 2016: 91). Özellikle Orta Doğu, Afganistan, Kafkaslar ve Afrika'da meydana gelen çatışma, kaos, istikrarsızlık ortamında Türkiye coğrafi konumu nedeniyle sığınmacıların ilk durağı olmakta ve bir çekim merkezi haline gelmektedir. Sığınmacı ve mülteciler gözünde Türkiye bazen bir geçiş ülkesi, bazen bir hedef ülke olmakta ve bu durum Türkiye'ye büyük mali ve sosyal problemler yüklemektedir (Yıldız, Ünlü ve Sezer, 2014: 42). Türkiye'nin komşusuna düşen yangını söndürme ve sığınmacılara kucak açma çabası insanlığın bir gereği olmakla birlikte, bu konuda geliştirilen politikaların etkinliği ve doğru tutundurulması oldukça önemlidir. Türkiye'nin göç veren ülke konumundan göç alan ülke konumuna dönüşümü sürecinde mevcut yasa ve kurumların yetersizliği ve hazırlıksızlığı sığınmacıların ve diğer amaçlarla ülkeye gelen yabancıların farklı sorunlarla karşılaşmasına neden olmaktadır (Erder, 2010: 43).

Göçler yaşandıkları coğrafyalarda kısa ve uzun vadede önemli değişikliklere sebep olmaktadır. Sosyal açıdan yaklaşıldığında ulusal kimliğin zedelenmesi, sosyal devlet yapısında meydana gelebilecek olumsuzluklar; toplumda sığınmacılara karşı endişe, önyargı ve olumsuz tutumların gelişmesine sebep olabilmektedir. Ekonomik açıdan yaklaşıldığında ise ucuzlayan işgücü sebebiyle hâlihazırda istihdam edilenlerin gelirinin azalması gibi etkiler doğabilmektedir. Nitekim ekonomik hayata katılan sığınmacılar emek arzının artmasına sebep olmuş ve emek gelirinin düşmesine yol açmıştır. Ayrıca sığınmacılara çalışma izni verilmesi özellikle yoğun olarak ikamet ettikleri illerde işgücü piyasasındaki rekabeti artırmış, işsizlik rakamlarını olumsuz etkilemiştir (Boz, 2016: 148-150). ilttica ve mültecilik tek başına ne politik, ne etik, ne kültürel bir sorundur aksine bunların bir bileşkesidir (Işıklı, 2015: 55) ve bu gerçek ışığında sorun ele alınmalıdır. Bu bağlamda bu araştırmada yoğun sığınmacı nüfusa sahip üç ilde, yerli halkın sığınmacılara ve birlikte yaşamaya ilişkin algılarını ve tutumlarını ölçmek amaçlanmıştır. Bu sayede sığınmacılara ilişkin politikaların halk tarafından nasıl yorumlandığı tespit edilecek ve politikanın pazarlanması noktasındaki eksikliklere ilişkin çıkarımlarda bulunulacaktır. 


\section{Kavramsal Çerçeve}

Yaşadığımız çağı göç çağı olarak adlandırmak mümkündür (Ünal, 2014: 66). Zorunlu göç olgusu edebiyatta, sinemada, medyadaki temsillerinde büyük trajedi anlatımlarına konu olmaktadır. Bu deneyimin aktörleri ise birer rakamdan ibarettir yani her büyük hikayede olduğu gibi görünmezdirler. Bundandır ki zorunlu göç politikaları, uluslararası sözleşmeler insanlardan ziyade sınırları, devletleri ve o sınır ve devletlerin güvenliğini öncelikler. Bir olgu olarak göç, göç edenden daha görünürdür. Sığınmacılar göç hikayelerinin öznesi olamaz, özne göç olgusunun bizatihi kendisidir. Bu yaklaşım zorunlu göçmenlerin öznel deneyimlerini ihmal etmekte ısrarcldır. Oysa göçün gerçek kişilerce deneyimlenen bir süreci vardır. Göç etmek basitçe kaynak ülkeden hedef ülkeye varmak olmadığı gibi, geçilen sınırlar da basitçe bir ülke sınırı değildir. Bir ülkeyi terk etmek aynı zamanda gündelik hayatınızı, kendi habitusunuzu terk etmek demektir (Oğuz, 2015: 129-130). Bu nedenledir ki, göç araştırmaları olgunun sebep olduğu ekonomik, sosyal, kültürel değişimlerin yanı sıra biz ve ötekinin birlikte yaşam deneyimini de konu edinmeli ve meseleye insani bir bakış açısı sağlamalıdır.

Türkiye'nin de imzaladığı Cenevre Sözleşmesi’ne göre mülteci; “1951 öncesi Avrupa'da meydana gelen olaylardan dolayı, Avrupa ülkelerinden gelen ırkı, dini, milliyeti, belli bir sosyal gruba mensubiyeti, siyasi düşünceleri nedeniyle zulüm göreceği konusunda korku taşıyan, bu yüzden ülkesinden kaçmak zorunda kalan, geri dönemeyen ve başka bir ülkeye sığınmak zorunda kalan İçişleri Bakanlığı'nca mülteci statüsü tanınan yabancı uyruklu kişi ya da belli bir uyruğu olmayan vatansız kişi" olarak tanımlanmaktadır. Sığınmacı ise "mülteci tanımındaki kriterlere uygun olan ancak Avrupa ülkeleri dışındaki ülkelerden gelen ve İçişleri Bakanlığı'nca sığınmacı statüsü tanınan yabancı uyruklu bir kişi ya da belli bir uyruğu olmayan vatansız kişi olarak tanımlanmaktadır (Yıldız, Ünlü ve Sezer, 2014: 43). Cenevre Sözleşmesi sonrası 1967'de imzalanan New York Protokolü'nde ise sözleşmedeki iki sınırlama metinden çıkarılmıştır. Bu sınırlamalar "1951'den önce" ve "Avrupa ülkelerinden gelen" ibareleridir. 1 Temmuz 1968 tarihli Bakanlar Kurulu kararı ile New York Protokolü'ne katılan Türkiye, Cenevre Sözleşmesi'ne şerh hakkını coğrafik sınırlama amacıyla kullanmış ve Avrupa'dan gelen insanları mülteci kabul ettiğini beyan etmiştir (Kaypak ve Bimay, 2016: 90; Güney ve Konak, 2016b: 511). Bu tanımlar ışığında Türkiye'ye zorunlu göç eden Asya, Afrika ve Orta Doğu kökenli göçmenler mülteci statüsünde değil, sığınmacı statüsünde yer almakta; bu durum pek çok hukuki, ekonomik ve sosyal sorunu beraberinde getirmektedir.

Türkiye'nin göç politikası büyük ölçüde $A B^{\prime} y e$ üyelik süreciyle şekillenmektedir. Cenevre Sözleşmesi'ndeki coğrafi sınırlamanın kaldırılması $A B^{\prime}$ ye üyeliğin olmazsa olmaz şartlarından olmasına rağmen Türkiye bu sınırlamayı korumaktadır. Bu durum Türkiye'nin Avrupalılaşma ekseninde ele aldığı göç politikası geliştirme sürecinin, iç dinamiklerin de incelenmesiyle açıklığa kavuşturulabileceğine işaret etmektedir. 1980'lere kadar Türkiye, Avrupa dışından mülteci akını ile karşılaşma ihtimalini çok ciddiye almamış, ancak 80'lerin sonlarında bu durum değişmek zorunda kalmıştır. 90'lı yıllarda konuyla ilgili alan yazın incelendiğinde politikaların güvenlik endişesiyle yönlendiği görülmektedir. Söz konusu yıllarda Türkiye'nin göç sorunu Kürt sorunu ile ilişkilendirilerek incelenmiş ve bu sebeple güvenlik kaygısı ön planda tutulmuştur. 1994'te hazırlanan ilticaya ilişkin yönetmelikte bu kaygıların vurgulandığı gözlenmektedir. Arap Baharı sonrası yürütülen çalışmalarda ise güvenlik kaygısından ziyade mali külfet vurgusunun ağırlık kazandığı görülmektedir. Mülteciye ev sahipliğinin getirdiği mali ve sosyal yük kaygılara yol açmakta, karar alıcılar bu yükü başka ülkelerle paylaşma isteği taşımaktadır. Bu noktada, külfet paylaşımı söylemi bu alanda politika belirleyici bir başka söylem olarak ortaya çıkmaktadır. Bu 
söylem, aynı zamanda uluslararası göçün olumsuz etkilerine vurgu yapan ve bu sebeple mülteci korumasının başlı başına "sıkıntı verici" bir eylem olduğunu ima eden (Noll, 2003: 237 akt. Eroğlu, 2015: 217) bir söylemdir (Eroğlu, 2015: 211-217).

Sığınmacıların kitleler halinde gelmesi Türkiye'nin mülteci ve sığınmacılara yönelik uluslararası anlaşmalarını yeniden gözden geçirmesini ve yeni düzenlemelere gitmesini gerektirmiştir. Bu durum akademik ve kamusal alanda ulus devlet, vatandaşlık ve haklar ilişkisinin yeniden tartışılmasına sebep olmaktadır (Güney ve Konak, 2016: 115). Bu bağlamda, İçişleri Bakanlığı tarafından hazırlanan 6458 sayılı "Yabancılar ve Uluslararası Koruma Kanunu” 11 Nisan 2013'te yürürlüğe girmiştir. Bu kanun vasıtasıyla yabancılara tanınacak temel hak ve hürriyetler ile kamu düzeni ve güvenliğinin korunması arasında denge kurulması amaçlanmıştır. Ülkemizdeki yabancıların toplumla karşııılı uyumu amacıyla bakanlıkça çeşitli faaliyetler yürütülmektedir (Yıldız, Ünlü ve Sezer, 2014: 44).

İltica hakkı mülteci olarak hukuki bir statünün kazanılmasını ifade ederken, sığınma hakkı ile sığınmacı olmak bir statü kazanımını değil; kısa süreli, fiili bir barınma hakkını ifade etmektedir (Reçber, 2014: 251). Uluslararası hukukta geçici korumayı düzenleyen bağlayıcı nitelikte bir metin yoktur, bu sebeple bu koruma mülteci statüsünden daha düşük düzeyde bir korumayı içerir. Bu nedenle, geçici koruma esasında belli bir süreyi kapsamalı ve kalıcı statüye geçişte bir araç olmalıdır. Oysa Türkiye'de ilgili yönetmelik gereği geçici korumanın bir süre üst sınırı yoktur. Bu durum sığınmacıların hukuki statülerini daha da muğlak hale getirmektedir (Biner ve Soykan, 2016: 10). Misafirlik olarak isimlendirilen, ancak süre uzadığı için halkın algısında misafirlikten de çıkan bu durumun yasal bir karşılığının olmaması, esasında hem sığınmacıların temel haklara erişimini engellemekte hem de iki ülke insanının arasındaki çatışmayı artırmaktadır. Bunun yanı sıra, yerli halkın kaynakların sığınmacılara yağdırılıp, yerli halktan esirgendiği varsayımını da körüklemektedir.

Göç toplumsal bir hareketlilik olarak göç edenle, göç edilen yerin sakini arasında bir etkileşime sebep olmaktadır. Toplumsal değişim ve gelişimin tohumları işte bu etkileşim sayesinde atılmaktadır. Etkileşimin sorunlu olduğu toplumlarda ayrışma ve asimilasyon benzeri problemler gelişirken, sorunsuz olduğu toplumlarda kültürel zenginleşme ve entegrasyona bağlı toplumsal gelişim gözlenmektedir (Tümtaş ve Ergun, 2016: 1352). Göç, her ne kadar mekânsal bir değişiklik olarak görülse de ekonomik ve sosyokültürel arka planın değişmesiyle göç edenler kadar göç edilen yerlerin yerel halkı için de büyük etkiler doğuran toplumsal bir olgudur (Kaypak ve Bimay, 2016: 88-89). Yalnızca bir mekândan diğerine mekanik bir hareketlilik olmayan göç araştırılırken, bu hareketlilik sonrası devam eden süreçte göç edenlerin yeni mekanlarında deneyimlediği hayat; içinde yaşadığı sosyal, hukuki ve ekonomik ilişkiler de konu edilmelidir (Biner ve Soykan, 2016: 2). Söz konusu olan dış göç olarak nitelendirilecek bir zorunlu göç ise, bu ekonomik ve sosyokültürel değişimler şiddetini artırmakta, iki topluluk arasındaki uyum süreci güçleşmekte ve bu durum her iki taraf için de pek çok sorunun doğmasına sebep olmaktadır.

"Ebedi Barış Üzerine Felsefi Bir Deneme" (1960) başlıklı eserinde Kant, iltica ve konukseverlik sorununa kalıcı bir çözüm aramış ve yöneticileri filozofların ebedi barış önerilerini incelemeye davet etmiştir. Bununla birlikte ebedi barışın bir ideal arayışı olduğunu da vurgulamıştır. Kant'ın tespitinden hareketle Derrida (2000: 3) iki başlangıç önermesi geliştirir ve insanseverlikle değil, hakla ilgilendiğini ve dünya vatandaşlığı hakkının genel geçer misafirperverlikle sınırlandırılması gerektiğini ileri sürer (akt. Işıklı, 2015: 56). Derrida'ya göre misafirperverlik; ötekini ve onun içeri davet edilmesini mümkün kılacak yaratıcı bir dil geliştirmelidir. Geleneksel, bilimsel, teknik, yasal ve politik düzenlemelere sadakatle ya da itaatle konuksever olunamaz. Eğer bir karar kar- 
zarar hesabının çıktısıysa orada ahlaki değil, temkinli hareketten bahsedilmelidir (akt. Işıklı, 2015: 60). Oysa son yıllarda özünde bir insan hakkı olan göç, yaygınlaşan göçmen ve yabancı korkusuyla siyasallaşarak neredeyse ulusal güvenlik sorunu haline gelmiştir. Göçmen olmak suçlu olmakla eşdeğer görülmeye başlanmıştır. Dolayısıyla, ülkelerini savaşlar, siyasal istikrarsızlıklar ve ekonomik kaygılarla terk etmek zorunda kalan insan kitleleri yasalar karşısında korunmasızken suçlu konumunda kalmaya başlamıştır (Erder, 2010: 41-42).

Eşikteki yabancıya ev sahibinin konukseverliğini hissettiren ve bir davetin de başlangıcı kabul edilebilen "Kimsiniz?" sorusu Türkçe'de "Kim o?" olarak kullanılmakta ve kapı dışındakine bensen söylemiyle iletişim kurulacak biri olmaktan uzak, üçüncü bir şahıs yani bir yabancı olduğu hissini yaşatmaktadır. Kapı önündeki ilgisiz üçüncü şahıs, ev sahibiyle iletişim kurmaya çalışır. $O$ henüz dost veya düşman olduğu belli olmayan bir yabancıdır. Bu durum onu çoktan kapı eşiğindeki karşıt-öteki olarak konumlandırmıştır (Işıklı, 2015: 62). Bu sebeple, kimse uzun süre yabancı olarak yaşamak istemez. Egemenlik, sanat, gündelik yaşam vb. normallikten sapar, yabancı olmak anormallik alanına düşer ve dışlanır (ışıklı, 2015: 63). Bu yolla süreç aslında iyi niyetli bir ev sahipliğini amaçlarken; algısal olarak tehlikeli öteki, belirsiz yabancı tipolojisini yaratır. Yabancı sözcüğünün sonundaki ek ayakkabıcı sözcüğünde olduğu gibi sürekli bir birlikteliği, o işi yapmasa da onunla tanımlanabilir bir kimliği taşımaktadır. Yabancı da yerleşik hale gelse de sınırın ötesinde bir ülkede yabancılığından arınamadan yaşamaya devam eder (Işıklı, 2015: 60). Mülteciler ve sığınmacılar genellikle hayatın yok yerinde, yerleştirildikleri kamplarda, hayatın görünmez kıldığı insanlar olarak yaşarlar ve yerel halk tarafından onlara ilişkin sorunlarda dahi sorunları çıkaranlar olarak görülürler. Karanlık sularda umutlarının boğulmasına tanıklık edilir (Reçber, 2014: 248). Mühim olan iyi bir göç yönetimi politikasına sahip olmaktır. Avrupa ülkelerinin geri püskürtme politikasıyla dışladığı bu insanların çaresizliği karşısında sessiz kalmak, tarih karşısında mahcup olmak demektir (Kaypak ve Bimay, 2016: 106).

Man'a (2016: 1148-1151) göre modernite müphemliği ortadan kaldırma amacıyla kendi günah keçilerini arar ve bu kategoriye en fazla alınan modernitenin müphemliği yok etme idealine meydan okuyan yabancılar ve yabancılar içerisinde de göçmenlerdir. Modernizmin dünya görüşü, doğayı kavramak ve ön görülemeyen her şeyi peşinen engelleyerek doğaya hükmetmek üzerinedir. Bu sebeple bilinmeyen ve tanıdık olmayan şeyler ve gruplar tehdit olarak görülmekte ve dışlanmaktadır. Bu dışlama eğilimi çoğu zaman yok etmeye yönelik kararlı girişimlere dönüşebilmektedir Bauman (2003: 74). "Modernlik ve Müphemlik" adlı eserinde "Dostlar var, düşmanlar var. Bir de yabancılar" derken yabancının müphem, dolayısıyla modernizmi korkutan tarafına işaret etmektedir. Yazara göre modern devlet, bahçeci bir devlettir ve kendinden olanı beslenecek ve çoğaltılacak faydalı bitkiler olarak görürken; kendinden olmayan yabancıyı yok edilecek veya kökünden sökülecek yabani otlar olarak görmektedir. Bu vahşi otlar ancak bulunması gereken yerlerde bulunduklarında göz alıcı, eşsiz bir tür olabilirdi. Bizim bahçemizde, tasarımımızı ve düzenimizi bozan zararlı bir ota dönüşürlerdi (Bauman, 2004: 68 akt. Man, 2016: 1152). Türkiye Cumhuriyeti hükümetinin yaşanan süreçte bu bahçeci devlet anlayışını yıkmaya çalışan insancıl yaklaşımı, yabancının müphemliğiyle savaşmaktadır. Ancak bu savaşta başarılı olmanın ön koşulu, sığınmacılara ilişkin politikaların doğru pazarlanması ve etkin tutundurulmasıdır. Mevcut durumda sığınmacılara ilişkin olumsuz tutumları ortaya koyan araştırmalar esasında politikaların yerli halka yeterince tanıtılmamış olduğuna işaret etmektedirler.

Yabancılara karşı tutumları, grup aidiyetleri ile açıklamak da mümkündür. Bauman (2004: 47-64) biz ve onlar ayırımı için iki halkanın varlığından bahsetmektedir. ilki, birinci iç grup olarak adlandırılabilecek aile ve benzeri gruplardır. Bu gruplar güvenlik açısından konforludur. İkinci iç 
grup ise sınıf, toplumsal cinsiyet, millet gibi daha geniş grupları ifade etmektedir. Grup büyümüştür, biz hala mevcuttur ancak güven kendiliğinden menkul değildir ve grup üyeleri arasında derin çıkar çatışmaları mevcut olabilir. Bu farklılık ve çatışmalar biz olgusu ile kapatılmaya çalışıır. Bu ikinci gruplar, doğal yapıştırıcılardan mahrumdurlar ve grubun birliği inançlara ve duygulara yönelik sürekli uyaranlarla ayakta tutulmaya çalışılır. İç grupta bu dayanışmanın kurulması çabalarına genellikle bir dış gruba karşı düşmanlığın vazedilmesi ve uygulanması eşlik eder. Aksi takdirde iç gruba sadakat çağrılarının başarı şansı yoktur. Çünkü "öteki” doğası gereği konumlandırılış biçimiyle kötüdür, tehlikelidir, tehditkârdır ve huzur kaçırır. Bu sebepledir ki, iç grup üyelerinin dış grup üyelerine yaptıkları kötülükler ahlaki açıdan sorunlu görülmezken, dış grup üyelerinin çok daha küçük kötülükleri şiddetle mahkûm edilir (akt. Man, 2016: 1153).

Öteki söylemini yaratan düşünce dünyasında, öteki ile birlikte yaşamak mantıksal olarak imkânsızdır. Ayrım ve özdeşlik esasında "Siz kimsiniz?" ve "Kim o?” sorularının farklılığı gölgesinde sürer gider. Kimliği belirsiz bir maskeyle dolaşan, risk ve tehdit taşıyan yabancıyı içeriye, eve, şehre, medeniyete ve dünya görüşüne sorgusuz buyur etmeksizin konuksever olunamaz. Konukseverlik konuğu taşıdığı riskle sevmektir. Bu birliktelikten doğan risk ev sahibi için "bir daha sevememe", konuk için ise "bir daha kimsenin kapısını güvenle çalamama" riskidir ve ihmal edilemeyecek kadar büyük bir sorundur. Ev sahibi mevcut rahatlığını sürdürmek varken yabancıya kapısını açtığında, kendini sadece farklılığa değil, tehditlere de açmış olur. ìhtiyatlı düşünce sisteminde bu "Ağrısız başına çaput sarmak" demektir. Özdeşlik açısından yaklaşıldığında ise iki durum ortaya çıkar. Ev sahibi ya kendi düzenini misafire dayatma ve onaylatma gereği hisseder ya da içeri kabul edilerek yabancılıktan mülteciliğe terfi eden öteki, ev sahibinin organizmasına karışır ve onu dönüştürür. Sistem başkalaşım geçirir ve özdeşliğini yitirir (ışıklı, 2015: 69-70). Bu nedenle, ilticayı doğuran durumlarda yerli halkın zihnindeki tehlikeli öteki algısını yıkmak neredeyse imkânsızdır. Öteki algısı yıkılan yerli, kendisinin ötekileştirileceği kaygısıyla zırhını indirmemekte, kendini ve içeriyi korumaktadır. Bu algıyla baş etmek de ancak etkin bir pazarlama ve halkla ilişkiler çabasıyla mümkündür. İçerideki ev sahibi mülteciyle yüzleştiğinde kendisi olmayı koruyabileceği tutundurulabilmeli ve ev sahipliğinin hayati gerekçesi ona doğru anlatılmalıdır. Aksi takdirde, kapı dışında ve içindekinin uzlaşması ve barışçıl bir hayat sürmesi imkânsızdır.

Mülteci evinden uzakta olandır. Kendi sınırlarının ötesinde başkalarının sınırına dayanandır. Engel olamadığı bir savaşın dehşetinden emin olmak için yeryüzüne dağılan insanlar topluluğudur. Kendi sınırlarını aşıp başka sınırlara dayanmış olması, aynı zamanda sınırın ötesindeki yaşam koşullarının farklı olduğunu da göstermektedir. Sınırı tanrı misafiri kimliği ile aşan mülteci, içerideki düzenin tanrısallığını da kabul etmiş olur. O ev sahibinin misafiridir ve kapıyı çalıp tanrı misafiri olduğunu söylediğinde ev sahibini kutsuyor olduğunun da farkındadır (Işıklı, 2015: 6468). Illtica talebi ile verilen mültecilik kimliği sadece içeride geçerli geçici bir kimliktir. İçeri kabul edilen misafir, ev sahibinin sözleşmeyi onaylayarak onu kabul ettiği duygusunu bu durum başına kakılmasa bile derinden hisseder. "Ben bir misafirim. Evinde olmayan bir yabancıyım. Yabancı bir tehdittir." düşüncesine kapılır (Işıklı, 2015: 66). Sonuçta sığınmacı, yerli halkın gözündeki tehlikeli öteki algısını kanıksamaya başlar ve bu kabulleniş iki taraf arasındaki mesafeyi açma yönünde bir etki gösterir.

Yerinden olma ve mültecilik genelleştirilebilecek bir olgu değildir, ancak bu süreçte sığınmacıların tabi oldukları bürokratik kuralların, ortak yasal prosedürlerin kişisel tecrübeleri kolektif tecrübelere dönüştürdüğü de söylenebilir (Biner ve Soykan, 2016: I). Suriyeli sığınmacılar Tür- 
kiye'de kurdukları yeni hayatlarında yabancı bir gücün yasalarıyla düzenlenmiş, kendisine dayatılan bir alanda yani ötekinin mekânında oyunlarını kurup, geliştirdikleri taktiklerle ayakta kalmaya çalışmaktadırlar. Göç sonucu yerleştikleri bu alanda öteki olarak yaftalanmaları, yoksullukla baş etmeleri ve sosyal dışlanmaya maruz kalmaları hâkim stratejinin bıraktığı boşluklarda kendi taktiklerini hayata geçirmelerini zorunlu kılmaktadır (Deniz, Hülür ve Ekinci, 2016: 1080).

Geride bırakılan ama aslında bırakılamayan hayatla bağlantılı olma hali, göç edenin göç ettiği yerde yeni bir hayat kurma pratiklerini, yeni ülkeyle ilişkisini ve şartlarla baş etme mekanizmalarını etkilemektedir. Ülkesine geri dönebilme ihtimali ve buna dair umudu, sığınmacının geride bıraktığı hayat ve o hayatın içindeki karakterlerle ilişkisinin gücüyle belirmektedir (Biner ve Soykan, 2016: 4). Başlangıçta davetsiz bir misafir olarak görülen Suriyeli sığınmacıların ülkelerindeki olayların şiddetlenmesiyle geri dönme umutları her geçen gün zayıflamaktadır. Bu durum öz yeterlikleri zayıf olan ev sahibi kentlerin yüksek sığınmacı nüfusu ile baş edebilmesini güçleştirmekte (Kaypak ve Bimay, 2016: 93) ve söz konusu kentlerin yerel halklarında da kaynakların yerli olmayanlar için uzun süreli heba edildiği algısını oluşturmaktadır. Yerli halk, kentin fakirleştiğini hissetmekte ve devlet tarafından sığınmacılara uygulanan pozitif ayrımcılıktan rahatsız olmaktadır.

\section{Suriyeli Sığınmacıların Türkiye'de Karşılaştıkları Sorunlar}

Sosyal uyum zorluğu ve yarattığı çatışma, zenofobi, istihdam ve emekle ilgili konularda yaşanan sömürü ve adaletsizlikler, şehirlerin demografik yapılarının değişimi, iç siyasette etnik ve mezhepsel ayrılıkların yarattığı gerilimler uluslararası zorunlu göç nedeniyle Türkiye'de ortaya çıkan temel problemlerdendir (Kaya, 2015: 266). Bu problemler birbirinden oldukça farklı gibi görünse de zaman zaman yerli halkın ya da sığınmacıların karşılaştığı münferit bir problemin ekonomik, sosyal, siyasi vb. pek çok açıdan yankılarının olduğu görülmektedir.

Yerli halk göçmenlere karşı; ücretleri düşürme, yerli nüfusun işsizlik oranını artırma, doğurganlıklarıyla sosyal sistemi çökertme ve milli kimliği zedeleme gibi ekonomik, sosyal, kültürel veya politik argümanlar geliştirmektedir (Özekmekçi, 2010: 44 akt. Ünal, 2014: 67). Genç (2014: 1) bu argümanların özellikle yerel ölçekte etkileri hissedilebilen küresel ekonomik krizler gibi konjonktürel bunalımlar sonrasında çoğaldığını ve "göç ve göçmen sorununun" temel bir referans noktası olarak daha fazla kullanıldığını ifade etmektedir (akt. Ünal, 2014: 67). Bu bakımdan, konjonktürel olarak esasında göç politikalarının ya da göçmenlerin sebep olmadığı ekonomik sorunların da faturasının onlara kesilebildiği söylenebilir. Bu yaklaşım, yerleşikle sığınmacı arasındaki uçurumu daha da açmakta ve birlikte yaşama kültürünü zedelemektedir.

Geliş sürecinde travmatik yolculuklar, güvenli topraklara erişim, kaçakçılardan gördükleri kötü muameleler, kimliksizlik, korku, endişe, konaklama gibi pek çok sorunla yüzleşen sığınmacılar; kalış sürecinde ise sığınma sistemine erişim, uzun bekleme süreleri, çalışma hakkı, ikamet, barınma, beslenme, sağlık, ilaç temini gibi konularda büyük sorunlar yaşamaktadır. Üçüncü bir ülkeye geçiş sürecinde ise yeni bir hayat, yeni bir ülke, dil, gelenek farklılığı, adaptasyon güçlüğü ve gelecek kaygısı ile yüzleşmektedirler (Yıldız, Ünlü ve Sezer, 2014: 44). Bütün bu sorunların yanı sıra, hem ilk göç ettikleri, hem de oradan geçtikleri üçüncü ülkede karşılaştıkları ırkçı muameleler, onların yerel halkla birlikte yaşama becerisi kazanmalarını geciktirmekte ve onları öteki konumuna mahkûm etmektedir. Bunun yanı sıra, esasında istihdam zorluğu nedeniyle beslenme, barınma, sağlık vb. ihtiyaçlarını yeteri düzeyde karşılayamayan sığınmacılar, yerel halk tarafından ekonomik ve sosyal imkânların sömürücüsü olarak görülmekte ve ülkedeki ekonomik sorunların ve geçim sıkıntısının müsebbibi olarak görülen günah keçilerine dönüşmektedir. Bu 
yaklaşımın değişmesinin yolu, sığınmacılarla ilgili devlet politikalarında güvenlik odaklı bir yaklaşımdan, insan hakları odaklı bir yaklaşıma geçilmesi ve insan hakları odaklı politikaların yerli halka doğru anlatılmasıdır. Dış politika ancak doğru tutundurulduğunda halk desteği alacak ve iki taraf arasında yaşanan sorunlar en aza indirilecektir.

İşücü piyasalarında dezavantajlı gruplardan olan mülteci ve sığınmacılar piyasa koşullarında pek çok ilişkiye girmek zorunda kalmakta ve bu ilişkilerde sömürülmeye bile değer bulunmayan bir kitle olarak görülmektedir (Reçber, 2014: 266). Göçmenler yerleştikleri şehirlerde ucuz işgücü olarak görülmüş ve yoksulluk girdabına mahkûm edilmişken, bir yandan da etnokültürel farklardan dolayı ayrıştırılmış ve ötekileştirilmeye varan uygulamalara maruz kalmışlardır. Bu dışlanmışıı onları Avrupa ülkelerine yasadışı göç teşebbüslerine zorlamış (Tümtaş ve Ergun, 2016: 1351) ve bu zorlama başka trajedilerin doğmasına sebep olmuş ve uluslararası kamuoyunun zihnine unutulması imkânsız karelerin kazınmasına yol açmıştır. Oysa ucuz işgücü olarak istihdam ediliyor olmaları onların yol açtığı bir sorun değil; aksine yerleşik işverenlerin hem onlara, hem de yerli çalışanlara yaptığı bir haksızlıktır.

Türkiye'de sığınmacıların yaşadıkları en önemli sorunlardan biri sosyal yardımlara erişim güçlüğüdür. İstihdam edilmeyen ya da yeterli geliri olmayan sığınmacılar için bu konu hayati öneme sahiptir. Yabancılar ve Uluslararası Koruma Kanunu'nda “ihtiyaç sahibi olan sığınmacıların sosyal yardım ve hizmetlere erişimi sağlanabilir" denmektedir. Bu madde, Türkiye'nin sığınmacılara karşı doğrudan bir sorumluluk almadığını, söz konusu kesimin sosyal yardımlara erişimini karar alıcıların inisiyatifine bıraktığını göstermektedir. Uydu kentlerdeki sığınmacılar için ayrı bir ödenek bulunmaması, sığınmacıların kente ekonomik bir yük olarak algılanmalarına sebep olmaktadır (Güney ve Konak, 2016: 117-118). Bu noktada sığınmacı kamplarında ikamet etmekte olanların sosyal yardımlara kendi imkânlarıyla şehrin muhtelif yerlerinde ikamet edenlerden daha kolay ulaştıkları söylenebilir. Ancak yine de yapılan sosyal yardımlar insana yaraşır bir hayatın sürdürülmesinde yetersiz kalabilmektedir. Bu sorunun aşılması için devletin yardımlarının, yerli halkta paylaşma kültürü oluşturularak desteklenmesi gerekmektedir. Yerli halkın bu noktada elini taşın altına koyması ancak sığınmacılarla ilgili devlet politikalarına güven duyması ile mümkündür ve bu güvenin sağlanması da esasında bir pazarlama sorunudur. Yerli halkın zihnindeki "Yardım, ona varsa bana yok." algısının yıkılması gerekmektedir.

Yetişkinlerin sebep oldukları savaşların, zorunlu göçlerin, yıkımların, ayakta kalma mücadelelerinin en büyük ve en masum mağdurları hiç şüphe yok ki çocuklardır. Suriye'de yaşananlar ve sonrasındaki süreç de en çok onları yaralamıştır. Onlar da yetişkinler gibi yeni bir ülkede, yabancısı oldukları insanlarla bir arada yaşamayı tecrübe etmiş; hatta yetişkinlerle çıktıkları umut yolculuklarında hayatını kaybetme gibi kötü sonuçlarla karşılaşmışlardır. Sığınmacı oldukları ülkelerde eğitimlerine devam eden sığınmacı çocuklar ayrımcılık, arkadaş edinememe, dil gibi sorunlarla karşılaşmakta ve bu sebeple toplumsal hayata entegrasyonları güçleşmektedir (Reçber, 2014: 258). Bunun yanı sıra, bugün eğitim hakları sınırlı olan bu sığınmacı çocukların ileride tümüyle bir kültürel kimlik kaybı yaşaması ihtimali de önemli bir endişedir (Kaypak ve Bimay, 2016: 102). Kendi dillerinde eğitim alma imkânlarının sınırlı oluşu ve Türk okullarında Türk çocukları ile iletişimlerinde yaşanan sıkıntılar Suriyeli çocukların eğitim hayatını güçleştirmektedir. Nitekim Biner ve Soykan'ın (2016) bulguları, Türk çocuklarının Suriyeli çocuklarla aynı sırada dahi oturmak istemediklerini ortaya koymaktadır. Bu sebeple, sığınmacıların ortak kaygısı bu akış içerisinde dilini, kültürünü unutmuş bir kuşağın yani kaybedilmiş bir kuşağın yetişmesidir. 
Bahsi geçen sorunların her biri oldukça önemli olmakla birlikte, toplumda yaygınlaşan nefret söyleminin en önemli sorunlardan biri olduğu söylenebilir. İnsan hakları sorunları arasında giderek üst sıralara yerleşen nefret söylemi ve suçları Türkiye'de belirgin şekilde artmakta ve bu söylem ve suçlar sığınmacı ve göçmenleri de hedef almaktadır. Bu davranışların kışkırtılmasında medyanın söz konusu gruba yönelik ötekileştirici ve dışlayıcı dili etkili olmaktadır (panel.stgm.org.tr akt. Yıldız, Ünlü ve Sezer, 2014: 49). Bununla birlikte bu durum ev sahipliği-misafirlik rollerinin yarattığı bir sahnedir. Ev sahibi misafiri içeri kabul ettiğinde misafir ev sahibine itaat etme eğilimine girer. Mültecilikte itaat bütün bir yerli halka itaate dönüşür. Bu durum esasında mülteci ile mukim arasındaki yazılı olmayan bir müzakeredir (Işıklı, 2015: 64). Mülteci içeri kabul edilmesinin ve içerde güvenli, korunaklı bir mekâna sahip olmasının karşılığını itaatiyle ödemek zorunda kalır. Göçmenlere ilişkin algıları ve göçmenlerin sorunlarını konu edinen araştırmalarda güvenlik kaygısının dile getirilmesi dikkat çekicidir. Bu durum konuya dair bir söylem sorununun da var olduğunu göstermektedir. Savaş ve iç kargaşa sebebiyle psikolojik travma yaşayan göçmenler "tehlikeli öteki" konumuna getirilmektedir. Sığınmacı-güvenlik kelimelerinin eşleştirilmesi kriminalleştirme ve patolojikleştirmeye dönüşmektedir (Güney ve Konak, 2016b: 508). "Öteki"yi ortaya çıkaran en önemli özellik düzeni bozma potansiyelidir. "Biz" ne kadar düzeni bozmayacak, istikrarsızlık yaratmayacak, toplumun varlık amacına uyanı temsil ediyor ise; öteki de o kadar düzeni bozan, gelenek, yasa ve normların içini boşaltan, tehlikeli olanı temsil etmektedir. Bu noktada, öteki biz tarafından güveni ve rahatlığı tehdit eden potansiyel düşman olarak görüldüğü için korkulan ve kaçılması gereken olarak konumlanmaktadır (Ünal, 2014: 79). Bu konumlandırma, yerleşik ile sığınmacı arasındaki ilişkiyi olumsuz etkileyecek bir güce sahiptir. Öteki konumlandırmasının yaygınlaşması aynı zamanda sığınmacıların değil, yerleşiğin sorunlarının yaygın olarak konuşulması sonucunu doğurmakta ve bu konuda etkin politikaların geliştirilmesi çabalarını geciktirmektedir. Sı ğınmacıların deneyimledikleri sorunlar sümen altı edilirken, yerleşiğin günlük pratikte yaşadığı her türlü sorun sığınmacıların varlığıyla ilişkilendirilmeye başlanmıştır.

\section{Literatür Taraması}

Göç ile yaşanan mekânsal hareket yalnızca bir transfer olarak değil, bir sosyal çevreden diğerine geçiş olarak nitelendirilmelidir. Bu geçiş esnasında, önceki sosyal bağlar zayıflayabileceği gibi, güçlenebilir veya tamamen kopabilir. Bu sebeple uluslararası göç incelenirken sosyolojik bir analiz için üç düzey geçerlidir: geride bırakılan ülke; geride bırakılan ülkede ait olunan sosyal gruplardaki bağlılığın gücü ve yoğunluğu; göç edenin kararında özgürlüğü ve kararın iradiliği (Faist, 2010: 67 akt. Biner ve Soykan, 2016: 2). Bu sebeple, göç üzerine yürütülen araştırmalarda bağlam oldukça önemli hale gelmektedir. Uluslararası göçün "şiddeti üreten tarafların bile artık ayrıştırılamadığı bir kaos hali" (Biner ve Soykan, 2016: 4) olarak tanımlanan iç savaş gibi bir zorunluluktan kaynaklanması ile geçim sıkıntısı ya da gelecek tahayyülü gibi bireysel bir sebepten kaynaklanması birbirinden farklı durumlardır. Bunun yanı sıra, zorunlu göçlerde de göç edenlerin kimliği ve göç edilen ülkenin kimliği göçün sonuçları üzerinde önemli etkileri olan değişkenlerdir. Bu sebeple yabancı literatürde göç üzerine yapılmış çok çalışma olmasına rağmen göç olgusunu bağlam doğrultusunda inceleyebilmek için, yerli literatürde Suriyeli göçmenler üzerine yapılmış çalışmalarla ilgili bulgular özetlenecektir.

Kömürcü, Özsoy ve Çobanoğlu (2011) Isparta'daki sığınmacı kadınlar üzerine yaptıkları nitel araştırmada katılımcı kadınların tamamının ülkelerindeki savaş ve şiddetten kaçtıklarını, kaçış sürecinin travmalarının izlerinin hala taze olduğunu, bekleme sürelerinin uzamasından dolayı 
endişeli olduklarını, çalışma izinleri olmadığı için ekonomik zorluklar yaşadıklarını ve ülkelerindeki baskıcı kültürel ortamın hala etkisinde olduklarını tespit etmişlerdir.

Yıldız, Ünlü ve Sezer (2014) Türkiye'de ikamet eden sığınmacılarda görülen sekiz farklı cinnet veya intihar vakası üzerinden gerçekleştirdikleri çalışmalarında, mülteci ve sığınmacılara yönelik ayrımcı, hoşgörüsüz, nefret içerikli tutumların önüne geçilmesi için toplumsal farkındalığı artırıcı çalışmalara ihtiyaç olduğunun altını çizmektedirler. Yazarlar mültecilerin ve sığınmacıların sosyal hayata entegrasyonu için yerel kamu idaresi, STK'lar ve üniversitelere çok iş düştüğünü belirtmektedirler.

Ünal (2014) blog ve forumlarda Suriyeli göçmenlere ilişkin yorumlar üzerine yaptığı araştırmada göçmenlerin bilinmezlikler ve kaygılarla dolu bir korku alanı olarak görüldüğü üzerinde durmaktadır. Paylaşımlarda göçmenlerin "vatan haini" olarak görüldüğü ve "Arap etnik kimliği"ne ilişkin negatif görüşlerin ağır bastığı söylenebilir. Araştırma bulgularına göre, Suriyeli sığınmacılar tehlikeli öteki olarak görülmenin yanı sıra hak etmeden ekmeğimizi bölüşmek zorunda bırakıldığımız bir topluluk olarak algılanmaktadır. Blog ve forumlardaki yorumlarda ırkçı söylemlerin ağırlıkta olduğu görülmektedir.

Atasü Topçuoğlu (2014) bir müracaatçı grubu olarak göçmen çocukları konu edinen araştırmasında mevzuya sosyal hizmetler bakış açısıyla yaklaşmıştır. Yapılan nitel araştırmada farklı ülkelerden savaş, ekonomik istikrarsızlık, eğitim vb. amaçlarla Türkiye'ye refakatli ya da refakatsiz göç eden 26 göçmen çocukla yarı yapılandırılmış mülakatlar gerçekleştirilmiş ve veriler çocuk hakları ihlalleri ve istismar üzerinden analiz edilmiştir. Araştırma sonuçları, göçmen çocukların yoğun bir şekilde hak ihlali ve istismara maruz kaldığını göstermektedir. Bu sebeple, yazar, göçmen çocukların sosyal politikalar geliştirilirken pozitif ayrımcılığa tabi bir grup olarak değerlendirilmeleri gerektiğini düşünmektedir.

Kaya (2015) Şanlıurfa'da faaliyet gösteren resmi ve gayri resmi derneklerin yöneticileriyle gerçekleştirdiği nitel araştırmada Türkiye'de yaşamakla ilgili algılarını konu edinmektedir. Araştırma bulguları, kültürel yakınlıktan dolayı Şanlıurfa'daki sığınmacıların diğer şehirlerde ikamet edenlerden daha memnun olduklarını, bununla birlikte bazı sıkıntıların yaşandı̆̆ını göstermektedir. Sığınmacıların hoşnutsuz oldukları temel konular kadınlara yönelik cinsel istismar, resmi nikâhsız ikinci evlilikler, emeğin sömürülmesi, ticarette aldatılma ve ayrımcılık gibi konulardır. Sığınmacılar, özellikle kadınlarının ve çocuklarının korunmasızlı̆̆ından zaman zaman faydalanıldığını düşünmektedir.

Apak (2015) Mardin'de yaşayan Suriyeli sığınmacıların gelecek beklentilerini konu edindiği araştırmasında sığınmacıların Türkiye'yi tercih etme sebeplerinin, sadece savaştan kaçmak olmadığını, bununla birlikte istihdam ve sosyal imkânlardan yararlanma ve vatandaşlık alma ümidiyle geldiklerini tespit etmiştir. Katılımcıların üçte ikisi TC vatandaşı olmak istediklerini beyan etmişlerdir.

Oğuz (2015) alan araştırması için pek çok farklı ülkeden sığınmacının ikamet ettiği Gaziantep'i seçtiği nitel araştırmasında yerleşikle sığınmacının birlikte deneyimledikleri gündelik hayatı konu edinmiş ve hem yerleşik hem de sığınmacılardan katılımcı gözlem, derinlemesine mülakat ve informal görüşme teknikleriyle veri toplamıştır. Araştırma sonuçları, aslında aynı mekânlarda yaşamaya devam eden yerleşik ve sığınmacının gerçek anlamda bir birliktelik yaşamaktan uzak durduklarını göstermektedir. Sığınmacılarda bunun sebebi yetkili mercilerce temkinli olma konusunda uyarılmaları iken, yerleşiğin temel sebebi kendinden uzak, tehlikeli, bilinmeyen olarak görülen yabancı algısına sebep olan milliyetçiliktir. Yerleşik sığınmacıları kentte istememekte, 
onları pis ve belirsiz işler yapan kişiler olarak tanımlamaktadır. Sığınmacıların yerleşikle uyum sağlayamamasının en önemli sebebi ise dil sorunudur.

Biner ve Soykan (2016) araştırmalarında konuya diğer tarafın penceresinden yaklaşmış ve Gaziantep'e göç eden sığınmacıların deneyimlerini konu edinen bir nitel araştırma gerçekleştirmiştir. Araştırma sonuçları, Suriyeli sığınmacıların Türkiye'yi ülkelerindeki koşullar değişene kadar hayatlarını idame ettirebilecekleri bir liman, ülkelerindeki gelişmeleri takip edebilecekleri bir gözlem yeri olarak gördüklerini ortaya koymaktadır. Yapılan görüşmelerde Türkiye'nin aslında, onlara karşı sevgisi ve merhametinin göstergesi gibi görünen "misafirlik" ifadesinin aynı zamanda bir geçicilik çağrışımı yaptığı ve hukuki bir geçerliliği olmadığı için de onlarda endişeye sebep olduğu üzerinde durulmuştur. Sığınmacılar, yerli halkın sığınmacıların zengin olanlarından bu misafirliğin ekonomik bedelini ödemelerini, diğerlerinden ise güçlerini çalışarak, onların razı olduğu değil piyasanın beklediği fiyattan kullanıma sunmalarını beklediğini düşünmektedir. Bunu başaramayan sığınmacıların ise, yeni bir ülke arayışına girmesi gerektiğini ifade etmektedirler.

Boz (2016) Suriye'den Türkiye'ye yaşanan dış göçün sosyoekonomik etkilerini konu edindiği araştırmasında istihdam, işgücü piyasasındaki rekabet, maddi imkânlarının adaletsiz dağıtımı, kiralardaki artış, iki ülke arasındaki ithalat-ihracat potansiyelindeki değişim vb. başlıklar üzerinde durmaktadır. Yazar yoğunluğu artan göç hareketlerinin Türkiye ekonomisi üzerinde olumsuz etkilerinin her geçen gün biraz daha artacağını ve bu durumun sosyal hayattaki çatışmaları da tetikleyeceğini düşünmektedir. Olası kargaşa ve kutuplaşmaların önüne geçmek için sığınmacıların sağlam temellendirilmiş politikalarla ekonomik hayata entegre edilmelerinin gerektiği belirtilmektedir. Başta eğitim olmak üzere her alanda Suriyeli sığınmacılar toplumsal hayata katılmalı, güven duygusu karşılıklı olarak pekiştirilmelidir.

Deniz, Hülür ve Ekinci (2016) Gaziantep ve Kilis'te yaptıkları çalışmada yerleşik kültürün var olduğu bir topluma kısa sürede şehir kültürünü etkileyecek yoğunlukta bir göçmen kitlesinin gelmesi gündelik hayatı nasıl etkiler sorusundan hareket etmişlerdir. İki ilde sığınmacılar ve yerli halkla yapılan derinlemesine mülakatlar yerli halkın stratejilerine karşılık, sığınmacıların geliştirdikleri taktikler bağlamında analiz edilmiştir. Araştırma bulguları sığınmacıların güçlü tarafın stratejileriyle baş etmek için kullandıkları taktiklerin yerli halk gibi giyinmek, kayıtsız da olsa bir evden birden fazla kişinin çalışması, işletilen mekânlara Türk bayrağı asılması, Türkçe öğrenmek gibi taktiklerdir. Yerli halkla yapılan görüşmeler ise, onların "evlerinin" Suriyeliler tarafından işgal edildiğini hissettiklerini, sığınmacıları kargaşa çıkaran istenmeyen topluluk olarak gördüklerini, genel olarak sığınmacılara güvenmediklerini, ülkelerinde kalıp savaşmadıkları için vatan haini olarak görüldüklerini göstermektedir.

Devran ve Özcan (2016) mecliste grubu bulunan siyasi partilerin 2011-2015 yılları arasındaki grup toplantısı konuşmalarında Suriye sorunu ve sığınmacılar konusundaki vurgularını konu edindikleri araştırmalarında eleştirel söylem analizine başvurmuşlardır. Araştırma sonuçları Adalet ve Kalkınma Partisi'nin söylemlerinde Suriyeli göçmenler için misafir, mülteci, kardeş, muhacir ve sığınmacı kavramlarını ağırlıklı olarak kullandığını; buna karşılık muhalefet partilerinin söylemlerinde Suriyeliler, göçmenler ve mülteciler söylemini tercih ettiklerini göstermektedir. Muhalefet partilerinin söylemleri daha resmi iken, iktidar partisinin söylemi hukuki olmaktan ziyade duygusal bir söylemdir.

Güney ve Konak (2016a) Bolu'da yerli halkın Irak ve Suriyeli sığınmacılara ilişkin tutumlarını kaynakların paylaşımı temelinde irdelemişlerdir. Araştırma bulguları yerel halkın sığınmacıları 
din kardeşliği temelinde benimsediklerini, aynı mekânlarda ibadet etmekten rahatsız olmadıklarını, ancak bu din kardeşliği algısının konu vatandaşlık olduğunda tersine çevrildiğini göstermektedir. Ekonomik ve sosyal kaynakların paylaşımı noktasında yerli halk vatandaşlık penceresinden bakıp, bu haklardan öncelikli olarak Türk vatandaşlarının yani kendi mağdurlarımızın faydalanması gerektiğini, devletin uyguladığı pozitif ayrımcılık politikalarının rahatsız edici olduğunu belirtmektedir. Ekonomik imkânlar konusunda görülen bu ötekileştirme tutumu, söz konusu sağlık yardımı ve sığınmacı çocukların eğitim hakları olduğunda gözlenmemektedir. Sağlık yardımlarının insan oldukları için elzem olduğu düşünülmektedir. Bunun yanı sıra konu sığınmacı çocuklar olduğunda yerli halk ötekileştirme tutumunu terk etmekte ve ücretsiz eğitim hakkının onlara da mutlaka sağlanması gerektiğini düşünmektedir.

Güney ve Konak (2016b) Bolu'da yerel halkın Iraklı ve Suriyeli sığınmacılara ilişkin öteki algılarını milliyetçilik, erillik ve vatandaşlık temelinde inceledikleri çalışmalarında; yerel halkın sığınmacıları vatana sadakatsizlikle suçladıklarını, bu sebeple erilliklerini sorguladıklarını ortaya koymaktadırlar. Toplumsal cinsiyet rolleri ışığında erkek sığınmacıların hem erillikleri, hem de milliyetçilikleri sorgulanmaktadır. Yerel halk yine sadakatsizlik temelinde sığınmacılara vatandaşlık hakkı verilmesine de tepki göstermekte, ülkelerine dönmeleri gerektiğini düşünmektedir. Bunun yanı sıra, kaynakları kendi vatanından savaşmadan kaçmış ve Türkiye'ye sadakati de şüpheli olan kitlelerle paylaşmak da istememektedirler. Araştırmanın bir başka bulgusu da, yerel halkın sığınmacılara tanındığını düşündükleri imtiyazların Türk vatandaşlarını üçüncü sınıf vatandaş konumuna getirdiğini düşünmesidir.

Kahraman ve Kahya Nizam (2016) Gaziantep'in sığınmacıların yoğunlukla yaşadığı bir mahallesinde yürüttükleri nitel çalışmada yerli yoksulun yabancı yoksul/sığınmacıya ilişkin düşünceleri belirlenmeye çalışılmıştır. Araştırma bulguları yerli yoksulların Suriyelileri adeta bir günah keçisi olarak gördüklerini; işsizlik, gelir adaletsizliği vb. yapısal sorunlardan bile onları sorumlu tuttuklarını, birlikte yaşamak istemediklerini, devletin kendilerine layık görmediği yardımları onlara yaptığını düşündüklerini, vatandaşlık hakkı verilmesine kesinlikle karşı olduklarını göstermektedir. Yerli yoksula göre yaşanan her türlü adaletsizliğin, ahlaksızlığın, karmaşanın, yoksulluğun müsebbibi aslında yoksul bile olmayan Suriyeli sığınmacılardır.

Kara, Yiğit ve Ağırman (2016) Çukurova Üniversitesi Türkçe Öğretmenliği bölümü öğrencilerinin Suriyeli mülteci algısı üzerine yaptıkları araştırmada öğrencilerin "Suriyeli mülteci...ya benzer, çünkü..." şeklinde metaforlar geliştirmelerini istemiş ve topladıkları verileri içerik analizine tabi tutmuşlardır. Araştırma sonucunda geliştirilen metaforlar yedi kategoride toplanmıştır. Bu kategoriler kimsesiz ve yardıma muhtaç, zarar veren, zarar gören, mücadeleci, değerli, çoğalan ve uyum sağlayan kategorileridir. Kategorilerin altında toplanan metaforlar incelendiğinde öğrencilerin büyük çoğunluğunun sığınmacıları bir sorun olarak tanımladıkları, çok azının "Suriyeli kardeşlerimiz" mealinde metaforlar geliştirdikleri görülmektedir.

Kaypak ve Bimay (2016) Batman'da mülteci ve sığınmacıların kente ekonomik ve sosyokültürel etkilerini konu edindikleri çalışmalarında sığınmacıların, getirdikleri sıcak para ile yerel yönetimin ise onlara yapılacak yardımları yerli esnaflardan temin yoluna gitmesi ile şehir ekonomisini önce canlandırdıklarını tespit etmişlerdir. Ancak yerli halkın bu algısı misafirliğin uzaması ile birlikte değişime uğramıştır. Gelen toplulukta şehrin sosyokültürel yapısıyla uyum sağlayamayacak etnik grupların varlığı yerli halkın en çok yakındığı konudur. Bunun yanı sıra, sığınmacıların düşük ücretlerle çalışmaya razı olması sonucu değişen istihdam durumu, artan konut kiraları, vergisiz esnaflık yapma girişimleri gibi olumsuzluklar Batman halkının yardımsever tutumlarını terk etmelerine ve mümkünse ülkelerine geri dönmelerini dillendirmelerine yol açmıştır. 
Mamuk ve Şahin (2016) İstanbul'da düzensiz göçmen olarak yaşayan kadınların yaşadıkları sorunları konu edindikleri çalışmada, üçte birinin Türkiye'de yaşadığı süre içerisinde şiddete, dörtte birinin ise ayrımcılığa maruz kaldığını tespit etmişlerdir. Sığınmacı kadınların en sık yaşadıkları sorunlar sırasıyla yoksulluk, işsizlik, dil bilmeme, vatan özlemi, yalnızlık ve hüzündür.

Man (2016) Şanlıurfa'daki Suriyeli göçmenlere ilişkin algıları konu edindiği araştırmasında olumsuz algıların aslında bir günah keçisi arama girişimi olduğunu, ekonomik endişelerin istatistiklere göre gerçeği yansıtmadığını ve yerli halkın işsizliğinin sorumlusu olarak Suriyelilerin gereksiz yere suçlandıklarını ifade etmektedir. Araştırma sırasında yürüttüğü yapılandırılmamış ve yarı yapılandırılmış mülakatlar neticesinde şehirde dolaşan tehlikeli öteki hikâyelerinin rivayetlerden ibaret olduğunu, belgelendirilemediğini ve aslında pek çoğunun gerçeği yansıtmadığını tespit etmiştir.

Şanlıöz (2016) düzensiz dış göçün sebep olduğu ekonomik ve sosyal problemleri ve bunlara yönelik çözüm önerilerini konu edindiği çalışmasında şu önerileri getirmektedir: Ekonomik problemlerin çözümü noktasında Suriyeli göçmenlerin üretimin ve istihdamın sınırlı olduğu imalat sektöründe istihdama yönlendirilmesi ve mesleki eğitimlere tabi tutularak ara eleman olarak değerlendirilmelerinin fayda sağlayacağını ileri sürmektedir. Sosyal problemlerin çözümü noktasında ise yerli halkla sığınmacıları kaynaştıracak ve kültürel uyumu hızlandıracak gönüllük esasına dayalı dil, iletişim, yerel kültür öğeleri vb. konularda düzenlenecek eğitim programlarının katkı sağlayacağı düşüncesindedir.

Tarman ve Gürel (2016) sosyal bilgiler öğretmen adaylarının Suriyeli sığınmacılara ilişkin farkındalıklarını konu edindikleri araştırmalarında yarı yapılandırılmış mülakatlar yapmışlardır. Öğretmen adaylarına sığınmacılığı nasıl tanımladıkları, Türkiye'nin sığınmacı kabul politikasını nasıl değerlendirdikleri, farklı etnisitelerden sığınmacıların kabulü hakkında ne düşündükleri, bir sığınmacı ile komşu olma durumu hakkında ne düşündükleri, bir sığınmacıya evlerini kiralayıp kiralamayacakları, vatandaşlığa kabullerine nasıl yaklaştıkları, sığınmacıların sosyal hayatta ne gibi sorunlara yol açtıkları ve bu sorunların çözümü noktasındaki önerileri sorulmuştur. Araştırma bulguları, sığınmacıların yoğun olarak ikamet ettikleri yerleşim yerlerinden gelen öğretmen adaylarının sığınmacılara karşı daha negatif tutumlara sahip oldukları, sığınmacı nüfusunun seyrek olduğu yerlerden gelen öğretmen adaylarının ise duruma insan hakları perspektifinden yaklaşıp daha olumlu baktıklarını göstermektedir.

Yıldız ve Uzgören (2016) İzmir'de kamp dışında yaşayan Suriyeli sığınmacılar üzerine yaptıkları nitel araştırmada hem sığınmacıların, hem de yerli halkın bu birlikte yaşama deneyimine ilişkin algılarını konu edinmişlerdir. Suriyeli sığınmacılar, İzmir halkını genel olarak dost canlısı ve misafirperver olarak tanımlamaktadır. İzmir'in seçilmesindeki en önemli sebep ülkelerine uzak bir nokta olmasından dolayı daha emniyetli görülmesi ve İzmir'de ikamet eden arkadaş ve akrabalarıdır. Sığınmacıların en çok sıkıntı yaşadıkları konu istihdam ve ücretlendirme konusudur. Benzer işi yapan yerlilerden daha az ve düzensiz ücretle çalıştırıldıklarını, ailede en fazla bir kayıtlı göçmen olduğu için bir kişilik sosyal yardımın kalabalık aile fertlerinin ihtiyaçlarını karşılamada yetersiz kaldığını, sık sık iş değiştirmek zorunda kaldıklarını ve yerli halk tarafından kaynakları paylaşma noktasında eleştiri ve saldırılara maruz kaldıklarını belirtmektedirler. Kamu hizmetlerinden faydalanırken de, hem dil hem de yetersiz bilgilendirme sebebiyle sıkıntılar yaşadıklarını ifade etmektedirler. Sığınmacıların büyük çoğunluğu şartlar tatmin edici olur ve vatandaşlık hakkı da verilirse Avrupa'ya geçmek yerine Türkiye'de kalacaklarını, ülkelerindeki savaşın yakın zamanda biteceğine inanmadıklarını, bitse bile evleri, işleri ve imkânlarını kaybettik- 
leri için geri dönmek için çok da sebeplerinin kalmadığını belirtmektedir. Yerli halk ise Suriyelilere uygulanan açık kapı politikasının insanlığın bir gereği olduğunu, Suriyelilerle birlikte yaşamaya çok tepkili olmadıklarını; ancak ekonomik politikalar konusunda ülkenin hazırlıksız yakalandığını ifade etmektedirler. İzmir halkı Suriyeli sığınmacıların uzun dönemde statülerinin ne olacağının belirlenmesi gerektiğini, vatandaşlık tartışmalarının sonraya bırakılması gerektiğini, ancak statüleri netleşmezse seçim dönemlerinde siyasal malzeme olmaya devam etmelerinden kaygılandıklarını belirtmektedir.

Literatürdeki araştırmaların bir kısmı sığınmacıların sorunları ile ilgili iken, bir kısmı yerleşiklerin sığınmacıların yol açtığını düşündükleri sorunlarla ilgilidir. Bu araştırmada üç ilde yerleşik halkın sığınmacılara ilişkin algıları ve onların yol açtığını düşündükleri sorunlar tespit edilmeye çalışılacaktır.

\section{Araştırmanın Yöntemi}

Bu başlık altında araştırmanın amacı, anakütlesi ve örneklemi, veri toplama aracı ve veri toplama süreci, araştırma soruları ve araştırmanın sınırıııkları hakkında bilgi verilecektir.

\subsection{Araştırmanın Amacı}

Bu araştırmanın amacı, yoğun Suriyeli sığınmacı nüfusuna sahip üç ilde yerli halkın sığınmacılara ilişkin algılarını tespit etmektir. Bunun yanı sıra, yerleşik halkın sığınmacı kaynaklı olduğunu düşündüğü problemlerin tespitini yapmak ve devletin Suriyeli sığınmacılara ilişkin politikalarının doğru pazarlanıp pazarlanmadığını tartışmaya açmak da amaçlanmaktadır.

\subsection{Anakütle ve Örneklem}

Araştırmanın anakütlesini Tokat, İstanbul ve Mardin illerinde ikamet eden Türkiye Cumhuriyeti vatandaşları oluşturmaktadır. AFAD'ın 2015 yılı verilerine göre sığınmacı nüfusu bakımından Mardin 5. Sırada, İstanbul 1. Sırada yer almaktadır (Kaypak ve Bimay, 2016: 92). Tokat ilinin dâhil edilme gerekçesi ise hem sığınmacı nüfusun ağırlıkta olması hem de geçmişte önce Bulgaristan, sonra Afganistan, Orta Doğu'daki olaylar neticesinde en son da Irak ve Suriye kökenli sığınmacılara ev sahipliği yapmış olmasıdır. Şehirde halen Bulgaristan, Afganistan, Irak ve Suriye'den göçen sığınmacılar yerli halkla aynı yerleşim yerlerinde birbirlerinden izole olmadan ortak yaşamı tecrübe etmektedir. Araştırmanın örneklemi, söz konusu illerde kolayda örnekleme yöntemi ile seçilen 400 kişiden oluşmaktadır. Araştırmada zaman ve maliyet kısıtı, örnekleme çerçevesi belirlemenin güçlüğü ve konunun hassasiyeti dikkate alınarak tesadüfi olmayan örnekleme yöntemlerinden biri tercih edilmiştir.

\subsection{Veri Toplama Aracı}

Araştırma kapsamında öncelikle bir nitel çalışma yürütülmüş ve üç şehirde ikamet eden şehrin yerlisi kişilerle yarı yapılandırılmış mülakatlar yapılmıştır. Araştırma ekibinde her üç ilin de yerleşiği olan araştırmacılar yer almaktadır. Dolayısıyla, yarı yapılandırılmış mülakat verilerinin yanı sıra uzun süreli gözleme dayalı bilgiler de veri toplama aracının geliştirilmesinde kullanımıştır. Nitel çalışma neticesinde elde edilen veriler ölçek ifadelerine dönüştürülerek veri toplama aracı oluşturulmuştur. Bunun yanı sıra, ifadelerin geliştirilmesinde literatürdeki muhtelif çalışmaların bulgularından da faydalanılmıştır.

Araştırmanın veri toplama aracı üç bölümden oluşmaktadır. Birinci bölümde, sığınmacılara ilişkin politikaların katılımcılar tarafından nasıl algılandığını ölçmek amacıyla geliştirilen açık ve kapalı uçlu beş adet soru yer almaktadır. İkinci bölümde, nitel çalışma sonucu geliştirilen 5'li 
Likert tipi 30 ifade yer almaktadır. Üçüncü bölümde ise, katılımcıların demografik özelliklerini belirlemeye yönelik 6 adet kapalı uçlu soru bulunmaktadır.

\subsection{Araştırma Soruları}

Yerleşik halkın Suriyeli sığınmacılara ilişkin algılarını belirlemeye yönelik bu araştırma keşifsel nitelikte bir araştırmadır. Bu sebeple, araştırma hipotezleri değil araştırma soruları geliştirilmiştir. Araştırmanın cevap aradığı sorular şunlardır:

-Katılımcıların şehirlerinde ikamet eden Suriyeli sığınmacılara ilişkin genel algıları nedir?

-Suriyeli sığınmacıların şehirlerinde sebep olduklarını düşündükleri sorunlar nelerdir?

-Katılımcıların Suriyeli sığınmacılara ilişkin algılarında bir politika pazarlaması sorununun varlığından bahsedilebilir mi?

-Üç ildeki algılar farklılaşmakta mıdır?

-Katılımcıların demografik özellikleri sığınmacılara ilişkin algılarını farklılaştırmakta mıdır?

\subsection{Araştırmanın Sınırlılıkları}

Araştırmada zaman ve maliyet kısıtı, örneklem çerçevesini belirlemenin güçlüğü ve konunun hassasiyeti sebebiyle gönüllülük esasının önemli olması, tesadüfi olmayan örnekleme metotlarından kolayda örneklemenin tercih edilmesine sebep olmuştur. Bu durum, sonuçların evrene genellenememesi nedeniyle araştırmanın en önemli kısıtıdır.

\section{Bulgular ve Tartışma}

Katılımcıların demografik özelliklerine ilişkin bulgular aşağıdaki tabloda özetlenmektedir.

Tablo 1: Katılımcıların Demografik Özellikleri

\begin{tabular}{|c|c|c|c|c|c|c|c|}
\hline Değişken & & $f$ & $\%$ & Değişken & & $f$ & $\%$ \\
\hline \multirow{4}{*}{ Cinsiyet } & Kadın & 167 & 41,8 & \multirow{4}{*}{ Med. hal } & Evli & 192 & 48 \\
\hline & Erkek & 232 & 58,0 & & Evli değil & 205 & 51,3 \\
\hline & Cevapsız & 1 & 0,2 & & Cevapsız & 3 & 0,7 \\
\hline & Toplam & 400 & 100 & & Toplam & 400 & 100 \\
\hline \multirow{7}{*}{ Yaş } & $18-25$ & 148 & 37 & \multirow{15}{*}{ Meslek } & İşsiz & 10 & 2,5 \\
\hline & $26-35$ & 106 & 26,5 & & Ev hanımı & 20 & 5,0 \\
\hline & $36-45$ & 77 & 19,3 & & İşçi & 70 & 17,5 \\
\hline & $46-55$ & 52 & 13,0 & & Memur & 53 & 13,3 \\
\hline & 56 ve üstü & 16 & 4,0 & & S.M.Erbabı & 4 & 1,0 \\
\hline & Cevapsız & 1 & 0,2 & & Esnaf & 14 & 3,5 \\
\hline & Toplam & 400 & 100 & & Öğrenci & 97 & 24,2 \\
\hline \multirow{9}{*}{ Eğitim } & Okuryazar & 8 & 2,0 & & Çiftçi & 7 & 1,8 \\
\hline & ilkokul & 46 & 11,5 & & Emekli & 5 & 1,3 \\
\hline & Ortaokul & 32 & 8,0 & & Sanayici & 6 & 1,5 \\
\hline & Lise & 52 & 13,0 & & Ö.S.Çalışanı & 24 & 6,0 \\
\hline & Önlisans & 27 & 6,8 & & Akademisyen & 67 & 16,7 \\
\hline & Lisans & 156 & 39,0 & & Diğer & 22 & 5,5 \\
\hline & Lisansüstü & 78 & 19,5 & & Cevapsız & 1 & 0,2 \\
\hline & Cevapsız & 1 & 0,2 & & Toplam & 400 & 100 \\
\hline & Toplam & 400 & 100 & & & & \\
\hline \multirow{9}{*}{ Gelir } & 1000 TL'den az & 122 & 30,5 & & & & \\
\hline & $1000-2000 \mathrm{TL}$ & 105 & 26,3 & & & & \\
\hline & 2001-3000 TL & 63 & 15,7 & & & & \\
\hline & $3001-4000 \mathrm{TL}$ & 25 & 6,3 & & & & \\
\hline & 4001-5000 TL & 39 & 9,7 & & & & \\
\hline & 5001-6000 TL & 17 & 4,3 & & & & \\
\hline & 6001 TL ve üstü & 28 & 7,0 & & & & \\
\hline & Cevapsız & 1 & 0,2 & & & & \\
\hline & Toplam & 400 & 100 & & & & \\
\hline
\end{tabular}


Tablo 1 incelendiğinde örneklemde cinsiyet açısından erkeklerin, yaş açısından 18-35 yaş aralığının, medeni hal açısından evli olmayanların, eğitim açısından lisans ve üstü eğitim düzeyinin, meslek açısından öğrenci, iş̧̧i ve akademisyenlerin, gelir açısından 0-3000 TL aralığının ağırlıkta olduğu görülmektedir.

Veri toplama aracının ilk bölümünde katılımcılara, sığınmacılara ilişkin algılarını belirlemeye yönelik açık ve kapalı uçlu sorular sorulmuştur. Bu soruların ilki "Ülke sınırlarının komşu ülkenin göçmenlerine açılmasını nasıl karşılıyorsunuz?" sorusudur. Katılımcıların \% 30,3'ü olumlu, \% 44,3'ü olumsuz baktığını; \% 18,8'i bu konuda kararsız olduğunu, \% 6,8'i ise bu konuda fikrinin olmadığını belirtmiştir. Bu soruya cevap verenlerin gerekçeleri bir başka soruda sorgulanmıştır. Olumlu bakıyorum cevabını verenlerin gerekçeleri incelendiğinde en önemli gerekçelerin; insanın yaşam hakkı/sivillerin masumiyeti, muhtaç durumda olmaları, empati, insani yardım, ölümden kaçıyor olduklarının düşünülmesi, merhamet ve din kardeşliği gerekçeleri olduğu görülmektedir. Bunun yanı sıra, "güçlü Türkiye" imajının sağlanması için bu yaklaşımın gerekli olduğunu belirten katılımcılar da vardır.

İlgili soruya olumsuz bakıyorum cevabını verenlerin gerekçeleri incelendiğinde, en önemli gerekçelerin kamu düzenini bozmaları, ekonomik kaygılar, kendi vatandaşlarımızın muhtaç durumda olması, sebepsiz yere sığınmacılardan rahatsız olma ve sığınmacılara pozitif ayrımcılık yapıldığının düşünülmesi olduğu görülmektedir. Bu gerekçeler incelendiğinde, olumsuz algı ve tutumların genel olarak kamu düzeninin korunması ve ekonomiye ilişkin kaygılardan kaynaklandığı söylenebilir.

Illgili soruya kararsızım cevabını verenlerin gerekçeleri incelendiğinde, bu katılımcıların sığınmacılara kapıların açılmasının belirsiz sonuçları olabileceğini düşündükleri ve özellikle merhamet duygusu ve akılcı kaygılar arasında kalıp kararsızlık yaşadıkları söylenebilir. Kararsız olduğunu belirten katılımcılar ölümden ve savaştan kaçan masumlara kapıları açmanın insanlığın bir gereği olduğunu düşünmekte; ancak bu kararın sonuçları açısından kaygılı olduklarını belirtmektedirler. Söz konusu grubun vicdan ve akıl arasında sıkışıp kaldıkları söylenebilir.

"Yakın çevrenizde ikamet eden sığınmacı aile var mı?" sorusuna katılımcıların \% 43'ü evet, $\% 40,8^{\prime}$ i hayır, \% 16,2'si ise bilmiyorum yanıtını vermiştir. Veri toplama aracının ikinci bölümünde katılımcıların sığınmacılara ilişkin algılarını ölçmeye yönelik 5'li Likert tipi ifadeler yer almaktadır. ifadelerin aritmetik ortalamaları incelendiğinde katılımcıların en çok katıldıkları ifadelerin "Sığınmacıların geçimini çalışarak sağlamaları gerektiğini düşünüyorum.", "Sığınmacıların düşük ücretlerle çalışmaları yerli halkın iş bulmasını zorlaştırmaktadır.", "Sığınmacıların sayısının artması şehirdeki konut kiralarını artırmıştır.", "Kendi mağdurlarımızın sığınmacılardan önce düşünülmesi gerektiğini düşünüyorum." ve "Yerli halkın çalışarak kazandığı imkânlara sığınmacıların çalışmadan ulaşmaları adaletsizliktir." ifadeleridir. Katılımcıların en az katıldıkları ifadeler ise, "Sığınmacıların şehre kültürel zenginlik kattığını düşünüyorum.", "Sı̆̆ınmacıların şehrin işgücü piyasasını olumlu etkilediğini düşünüyorum.", "Kaynakları sığınmacılarla paylaşıyor olmak beni mutlu ediyor.", "Sığınmacılara elimden geldiğince yardımcı olmaya çalışııım." ve "Ülkelerinde mağdur olan sığınmacılara kucak açmamız gerektiğini düşünüyorum." ifadeleridir. Bu bulgular birlikte değerlendirildiğinde katılımcıların sığınmacılara ilişkin algılarının genel olarak olumsuz olduğu, bu olumsuzluğun ağırlıklı olarak ekonomik kaygılar etrafında şekillendiği ve sığınmacıların şehre ve ülkeye herhangi bir faydası olmayan topluluklar olarak görüldüğü söylenebilir. 
Veri toplama aracının yapı geçerliliğinin testi için açıklayıcı faktör analizinden yararlanılmıştır. "Sı̆̆ınmacılara devlet tarafından yapılan sosyal yardımlar onları tembelleştirmektedir." ifadesi binişiklik nedeniyle faktör analizinden çıkarılmış ve analiz tekrarlanmıştır. Veri setinin faktör analizi için uygun ve örnek hacminin yeterli olduğunu ortaya koymak amacıyla KMO ve Barlett test sonuçlarından faydalanılmıştır. Elde edilen sonuçlar, örneklem büyüklüğünün faktör analizi için yeterli olduğunu ve veri setinin faktör analizi için uygun olduğunu göstermektedir.

Faktör analizi neticesinde dört faktörlü bir çözüm elde edilmiştir. Elde edilen faktörler varyansın \% 62,445'ini açıklamaktadır. Analizin çıktıları aşağıdaki tabloda raporlanmaktadır.

Tablo 2: Açıklayıcı Faktör Analizi Sonuçları

\begin{tabular}{|c|c|c|c|c|}
\hline Faktörler & Özdeğ. & $\begin{array}{l}\text { Açılk. } \\
\text { Var. }\end{array}$ & Fakt. Y. & $\alpha$ \\
\hline Faktör 1: Ekonomik Kaygılar & 12,722 & 43,869 & & 94,5 \\
\hline $\begin{array}{l}\text { Göçmenlerle birlikte artan şehir nüfusu sebebiyle yerli halk daha fa- } \\
\text { kirleşmiştir. }\end{array}$ & & & ,776 & \\
\hline $\begin{array}{l}\text { Sığınmacıların yerleştiği şehirlerin ekonomileri bu durumdan olumsuz } \\
\text { etkilenmiştir. }\end{array}$ & & & ,752 & \\
\hline $\begin{array}{l}\text { Sığınmacılara kapılarımızın açılması ülkenin ekonomik durumunu } \\
\text { olumsuz etkilemiştir. }\end{array}$ & & & 749 & \\
\hline $\begin{array}{l}\text { Devletin sığınmacılarla ilgili politikaları yerli halkın ekonomik duru- } \\
\text { munu olumsuz etkilemektedir. }\end{array}$ & & & 740 & \\
\hline Sığınmacılar ülke ekonomisine büyük bir yük getirmiştir. & & & 729 & \\
\hline $\begin{array}{l}\text { Sığınmacıların istihdam edilmesi yerli halkın istihdam oranını azalt- } \\
\text { mıştır. }\end{array}$ & & & 718 & \\
\hline $\begin{array}{l}\text { Sığınmacıların düşük ücretle çalışmaları yerli halkın iş bulmasını zor- } \\
\text { laştırmaktadır. }\end{array}$ & & & 706 & \\
\hline $\begin{array}{l}\text { Yerli halkın çalışarak kazandığı imkânlara sığınmacıların çalışmadan } \\
\text { ulaşmaları adaletsizliktir. }\end{array}$ & & & 635 & \\
\hline $\begin{array}{l}\text { Sığınmacılara sunulan imkânlar yerli halk içerisinde ihtiyaç sahiplerin- } \\
\text { den esirgenmektedir. }\end{array}$ & & & 611 & \\
\hline $\begin{array}{l}\text { Yerli halkın rızası alınmadan, verdikleri vergiler sığınmacılara gitmek- } \\
\text { tedir. }\end{array}$ & & & ,591 & \\
\hline Sığınmacıların sayısının artması şehirdeki konut kiralarını artırmıştır. & & & ,587 & \\
\hline Sığınmacılar üretmeden tüketen kitlelerdir. & & &, 570 & \\
\hline Faktör 2: Pozitif Ayrımcılık Rahatsızlığı ve Hoşnutsuzluk & 2,742 & 9,456 & & 91,3 \\
\hline $\begin{array}{l}\text { Sığınmacıların merhamet duygumuzu istismar ettiklerini düşünüyo- } \\
\text { rum. }\end{array}$ & & & 724 & \\
\hline Sığınmacılar şehrin genel huzurunu kaçırmaktadır. & & & 705 & \\
\hline Sığınmacılar bizimle yaşamaya uyum sağlayamamıştır. & & & 692 & \\
\hline Sığınmacıların devlet tarafından kayırıldığını düşünüyorum. & & & 671 & \\
\hline $\begin{array}{l}\text { Kendi mağdurlarımızın sığınmacılardan önce düşünülmesi gerekti- } \\
\text { ğine inanıyorum. }\end{array}$ & & & 650 & \\
\hline $\begin{array}{l}\text { Sığınmacılara sahip çıkılmasının onların ülkelerine dönme ihtimalini } \\
\text { ortadan kaldırdığını düşünüyorum. }\end{array}$ & & & 647 & \\
\hline Sığınmacılara uygulanan pozitif ayrımcılıktan rahatsızım. & & & 641 & \\
\hline Sığınmacıların şehirdeki suç oranını artırdığını düşünüyorum. & & & 624 & \\
\hline Sığınmacıların durumdan istifade ettiklerini düşünüyorum. & & & ,588 & \\
\hline $\begin{array}{l}\text { Sığınmacıların sayıca çoğalması şehirde kültürel sorunların çıkmasına } \\
\text { sebep olmuştur. }\end{array}$ & & & ,587 & \\
\hline $\begin{array}{l}\text { Sığınmacıların geçimlerini çalışarak sağlamaları gerektiğini düşünüyo- } \\
\text { rum. }\end{array}$ & & & 459 & \\
\hline Faktör 3: Sığınmacılarla Birlikte Yaşamayı Onaylama & 1,376 & 4,745 & & 86,8 \\
\hline $\begin{array}{l}\text { Komşu ülkelerin vatandaşlarının yanında olmanın doğru bir tavır ol- } \\
\text { duğunu düşünüyorum. }\end{array}$ & & & 849 & \\
\hline
\end{tabular}




\begin{tabular}{|c|c|c|c|c|}
\hline $\begin{array}{l}\text { Ülkelerinde mağdur olan sığınmacılara kucak açmamız gerektiğini dü- } \\
\text { şünüyorum. }\end{array}$ & & & ,842 & \\
\hline Sığınmacılara elimden geldiğince yardımcı olmaya çalışııım. & & & 817 & \\
\hline Kaynakları sığınmacılarla paylaşıyor olmak beni mutlu ediyor. & & & 761 & \\
\hline Faktör 4: Sığınmacıların Olumlu Etkileri Olduğunu Düşünme & 1,269 & 4,375 & & 74,3 \\
\hline $\begin{array}{l}\text { Sığınmacıların şehrin işgücü piyasasını olumlu etkilediğini düşünüyo- } \\
\text { rum. }\end{array}$ & & & 859 & \\
\hline Sığınmacıların şehre kültürel zenginlik kattığını düşünüyorum. & & & ,787 & \\
\hline \multicolumn{5}{|c|}{ KMO= ,954; $x^{2}=7365,248 ; d f=406 ; p \leq 0,0001 ;$ Açıklanan Varyans: $\% 62,445$} \\
\hline
\end{tabular}

Faktörler altında toplanan ifadeler incelendiğinde; birinci faktörün ekonomik kaygılar, ikinci faktörün, pozitif ayrımcılık rahatsızlığı ve hoşnutsuzluk, üçüncü faktörün sığınmacılarla birlikte yaşamayı onaylama, dördüncü faktörün ise, sığınmacıların olumlu etkilerinin olduğunu düşünme olarak adlandırılmasının uygun olacağına karar verilmiştir. Faktör analizi çıktıları ölçeğin yapısal geçerliliğinin olduğunu göstermektedir. Bununla birlikte, tüm faktörlerin güvenilirlikleri arzu edilen sınırın üzerindedir.

Elde edilen faktörlerin katılımcıların demografik özellikleri itibariyle farklılaşıp farklılaşmadığı bağımsız iki örneklem t-testi ve tek yönlü varyans analizi ile test edilmiştir.

Kadın katılımcılar ile erkek katıımcıların elde edilen faktörler açısından algılarının farklılaşıp farklılaşmadığı bağımsız iki örneklem t-testi ile analiz edilmiştir. Yalnızca birinci faktör açısından kadınlarla erkekler arasında anlamlı farklılık vardır $(p=0,014 ; t=-2,481)$. Erkek katılımcılar sığınmacıların ekonomi üzerinde olumsuz etkilerinin olduğuna kadın katılımcılardan daha çok inanmaktadır. Sığınmacılarla ilgili politikaların ekonomi alanında olumsuz sonuçlarının olacağını düşünmektedirler. Bu farklıı̆̆ın sebebi erkeklerin işgücü piyasasında kadınlardan daha çok yer alıyor olmalarıdır. Bunun yanı sıra sığınmacıların istihdam edildikleri daha çok kas gücüne dayalı iş alanlarında kadın işgücü oranı oldukça düşüktür. Bu sebeple sığınmacıların düşük ücretlerle çaııştırılmaları sonucu yerli halkın istihdam sıkıntısı yaşayacağı korkusu erkek katılımcılarda daha baskındır.

Katılımcıların sığınmacılara ilişkin algılarının yaşları itibariyle farklılaşıp farklılaşmadığı tek yönlü varyans analizi ile test edilmiştir. Analiz sonuçları, yalnızca sığınmacıların olumlu etkilerinin olduğunu düşünme olarak adlandırılan dördüncü faktör açısından farklılaşmanın olduğunu göstermektedir $(p=0,039)$. Farklılığın yönünü görmek için Scheffe testi yapılmıştır. Test sonuçları, farkın yönünü göstermediği için LSD testi tercih edilmiştir. Test sonuçları aşağıdaki tabloda özetlenmektedir.

Tablo 3: Yaş Gruplarının Algıları Arasındaki Farkı Gösteren LSD Testi

\begin{tabular}{|c|c|c|c|c|c|}
\hline Değişken & $I$ & $\mathrm{~J}$ & Ortalama Farkı & Standart Hata & Anlamlılık \\
\hline \multirow{4}{*}{$\begin{array}{l}\text { Sığınmacıların olumlu etkileri- } \\
\text { nin olduğunu düşünme }\end{array}$} & $18-25$ & $\begin{array}{l}26-35 \\
36-45 \\
46-55 \\
56 \text { ve üstü }\end{array}$ & $\begin{array}{l}04073 \\
, 01084 \\
-, 42698^{*} \\
, 36149 \\
\end{array}$ & $\begin{array}{l}13465 \\
, 14869 \\
17059 \\
27849 \\
\end{array}$ & $\begin{array}{l}762 \\
, 942 \\
, 013 \\
195 \\
\end{array}$ \\
\hline & $26-35$ & $\begin{array}{l}36-45 \\
46-55 \\
56 \text { ve üstü }\end{array}$ & $\begin{array}{l}-, 02989 \\
-, 46771^{*} \\
, 32075 \\
\end{array}$ & $\begin{array}{l}15845 \\
, 17916 \\
, 28382 \\
\end{array}$ & $\begin{array}{l}, 850 \\
, 009 \\
, 259 \\
\end{array}$ \\
\hline & $36-45$ & $\begin{array}{l}46-55 \\
56 \text { ve üstü }\end{array}$ & $\begin{array}{l}-, 43781^{*} \\
, 35065\end{array}$ & $\begin{array}{l}18994 \\
\text {,29074 } \\
\end{array}$ & $\begin{array}{l}, 022 \\
, 229 \\
\end{array}$ \\
\hline & $46-55$ & 56 ve üstü & ,78846 & ,30253 & , 010 \\
\hline
\end{tabular}

LSD tablosu incelendiğinde, 46-55 yaş grubunun sığınmacılara karşı en olumlu algılara sahip yaş grubu olduğu görülmektedir. Sığınmacıların şehre ekonomik katkılarının olduğuna ve şehre 
kültürel zenginlik kattıklarına diğer yaş gruplarından daha çok inanmaktadırlar. Bu sonucun, büyük ölçüde istihdam dışı kalmak üzere olan bir yaş grubu olmalarından kaynaklandığı düşünülmektedir. İşgücü piyasasındaki olumsuz değişimleri gözlemleme şansı olmayan bir yaş grubu oldukları söylenebilir. Aynı durumun 56 ve üstü yaş grubunda da gözlemlenmesi beklenirken, bu yaş grubu diğer gruplardan farklı değildir. Beklentilerle uyuşmayan bu sonucun sebebinin 56 ve üstü yaş grubunun örneklemde sayıca az olması olduğu düşünülmektedir.

Katılımcıların sığınmacılara ilişkin algılarının medeni durumları itibariyle farklılaşıp farklılaşmadığı bağımsız iki örneklem t-testi ile analiz edilmiş ve anlamlı fark tespit edilememiştir. Yapılan tek yönlü varyans analizi sığınmacılara ilişkin algıların meslekler itibariyle de farklılaşmadığını göstermektedir. Katılımcıların algıları gelirleri itibariyle farklılaşmaktadır. Farklılı̆ın yönünü gösteren Scheffe testi sonuçları aşağıdaki tabloda özetlenmektedir. Tabloda yalnızca aralarında anlamlı farklılık olan gruplar raporlanmıştır.

Tablo 4: Gelir Gruplarının Farklılıklarını Gösteren Scheffe Testi

\begin{tabular}{|c|c|c|c|c|c|}
\hline Değişken & $\mathbf{I}$ & J & $\begin{array}{l}\text { Ortalama } \\
\text { Farkı }\end{array}$ & $\begin{array}{l}\text { Standart } \\
\text { Hata }\end{array}$ & Anlamlılık \\
\hline \multirow{3}{*}{ Ekonomik Kaygılar } & 1000 TL'den az & $1000-2000 \mathrm{TL}$ &,$- 45965^{*}$ & 11663 & ,018 \\
\hline & $1000-2000 \mathrm{TL}$ & $\begin{array}{l}\text { 4001-5000 TL } \\
5001-6000 \mathrm{TL} \\
6001 \mathrm{TL} \text { ve üstü }\end{array}$ & $\begin{array}{l}96154^{*} \\
1,08371^{*} \\
, 87912^{*}\end{array}$ & $\begin{array}{l}16566 \\
, 22862 \\
, 18606\end{array}$ & $\begin{array}{l}, 000 \\
, 001 \\
, 001\end{array}$ \\
\hline & $2001-3000 \mathrm{TL}$ & $4001-5000 \mathrm{TL}$ & ,71072* & 17950 & 017 \\
\hline \multirow{2}{*}{$\begin{array}{l}\text { Pozitif Ayrımcılık Ra- } \\
\text { hatsızlığı ve Hoşnut- } \\
\text { suzluk }\end{array}$} & $1000-2000 \mathrm{TL}$ & $4001-5000 \mathrm{TL}$ & ,69870* & 15827 & ,004 \\
\hline & $2001-3000 \mathrm{TL}$ & $4001-5000 \mathrm{TL}$ &, $63017^{*}$ & , 17150 & ,038 \\
\hline \multirow{2}{*}{$\begin{array}{l}\text { Sığınmacılarla Bir- } \\
\text { likte Yaşamayı Onay- } \\
\text { lama }\end{array}$} & $1000-2000 \mathrm{TL}$ & $4001-5000 \mathrm{TL}$ &,$- 91764^{*}$ & , 18546 & 001 \\
\hline & 2001-3000 TL & 4001-5000 TL &,$- 84785^{*}$ & ,20096 &, 008 \\
\hline \multirow{2}{*}{$\begin{array}{l}\text { Sığınmacıların } \\
\text { Olumlu Etkilerinin } \\
\text { Olduğunu Düşünme }\end{array}$} & $1000 \mathrm{TL}^{\prime}$ den az & $4001-5000 \mathrm{TL}$ &,$- 72217^{*}$ & ,19327 & 032 \\
\hline & $2001-3000$ TL & 4001-5000 TL &,$- 87030^{*}$ & 21368 & 012 \\
\hline
\end{tabular}

1000-2000 TL gelir grubu sığınmacıların ekonomi üzerinde olumsuz etkilerinin olduğuna 1000 TL'den az gelir grubu ile 4000 TL ve üstü gelire sahip gruplardan daha çok inanmaktadır. Bu durumun, büyük ölçüde işgücü piyasasında istihdam edilmek için sığınmacılarla en çok rekabet içerisinde olan gelir grubu olmalarından kaynaklandığı düşünülmektedir. 1000 TL'den az gelire sahip olanlarda aynı durumun söz konusu olmaması ise bu grubun büyük ölçüde henüz işgücü piyasasına dâhil olmayan öğrencilerin yer aldığı gelir grubu olmasıyla açıklanabilir. Üst gelir grupları ise, ekonomiyle ilgili çok kaygılı değildir. Bu durum sığınmacıların istihdam edildikleri alanların dışında istihdam edilmeleri ile açıklanabilir.

1000-2000 TL ve 2001-3000 TL gelir aralıkları 4001-5000 TL gelire sahip olanlara göre pozitif ayrımcılıktan daha çok rahatsızdırlar ve sığınmacılarla birlikte yaşamaktan daha hoşnutsuzdurlar. Bu gelir grupları, sığınmacıların aldıkları sosyal yardımların bir kısmından faydalanan ya da faydalanmayı arzu eden gelir gruplarıdır. Ancak sığınmacılara yapılan pozitif ayrımcılıktan dolayı söz konusu kaynaklara eskisi kadar kolay ulaşamadıkları düşünüyor olabilirler.

4001-5000 TL gelire sahip katılımcılar, 1000-3000 TL aralığında gelire sahip olanlara göre sığınmacılarla birlikte yaşamaya daha olumlu yaklaşmaktadır. Bu durum, işgücü piyasasında sığınmacılarla rekabet halinde olmayan bir gelir grubu olmalarından kaynaklanabilir. Benzer şekilde, 4001-5000 TL gelire sahip katılımcılar sığınmacıların ekonomik ve kültürel anlamda olumlu 
etkilerinin olduğuna da 1000 TL'den az ve 2001-3000 TL aralığında gelire sahip olanlardan daha çok inanmaktadır.

Katılımcıların sığınmacılara ilişkin algılarının sığınmacılara ilişkin genel değerlendirmeleri açısından farklılık gösterip göstermediği tek yönlü varyans analizi ile test edilmiştir. Tüm faktörlerde anlamlı farklılık tespit edilmiştir. Farklılığın yönünü gösteren Scheffe testi sonuçları aşağıdaki tabloda özetlenmektedir.

Tablo 5: Sığınmacılara iliş̧kin Genel Değerlendirmeler Açısından Farklılıkları Gösteren Scheffe Testi

\begin{tabular}{|c|c|c|c|c|c|}
\hline Değişken & I & J & Ortalama Farkı & Standart Hata & Anlamlılık \\
\hline \multirow{3}{*}{ Ekonomik Kaygılar } & Olumlu & $\begin{array}{l}\text { Olumsuz } \\
\text { Kararsız } \\
\text { Fikri yok }\end{array}$ & $\begin{array}{l}-1,27145^{*} \\
-, 45855^{*} \\
-, 72202^{*}\end{array}$ & $\begin{array}{l}, 08847 \\
, 11022 \\
, 15963\end{array}$ & $\begin{array}{l}, 000 \\
, 001 \\
, 000\end{array}$ \\
\hline & Olumsuz & $\begin{array}{l}\text { Kararsız } \\
\text { Fikri yok }\end{array}$ & $\begin{array}{l}, 81290^{*} \\
, 54942^{*}\end{array}$ & $\begin{array}{l}10333 \\
\text { 15495 }\end{array}$ & $\begin{array}{l}\text {,000 } \\
\text {,006 }\end{array}$ \\
\hline & Kararsız & Fikri yok &,- 26348 & 16832 &, 485 \\
\hline \multirow{3}{*}{$\begin{array}{l}\text { Pozitif Ayrımcılık Rahat- } \\
\text { sızlığı ve Hoşnutsuzluk }\end{array}$} & Olumlu & $\begin{array}{l}\text { Olumsuz } \\
\text { Kararsız } \\
\text { Fikri yok }\end{array}$ & $\begin{array}{l}-1,12275^{*} \\
-, 49455^{*} \\
-, 78788^{*} \\
\end{array}$ & $\begin{array}{l}08442 \\
, 10518 \\
, 15233 \\
\end{array}$ & $\begin{array}{l}, 000 \\
, 000 \\
, 000 \\
\end{array}$ \\
\hline & Olumsuz & $\begin{array}{l}\text { Kararsız } \\
\text { Fikri yok }\end{array}$ & $\begin{array}{l}62821^{*} \\
, 33487\end{array}$ & $\begin{array}{l}09861 \\
, 14787 \\
\end{array}$ & $\begin{array}{l}, 000 \\
, 164 \\
\end{array}$ \\
\hline & Kararsız & Fikri yok &,- 29333 & ,16062 & ,344 \\
\hline \multirow{3}{*}{$\begin{array}{l}\text { Sığınmacılarla Birlikte } \\
\text { Yaşamayı Onaylama }\end{array}$} & Olumlu & $\begin{array}{l}\text { Olumsuz } \\
\text { Kararsız } \\
\text { Fikri yok }\end{array}$ & $\begin{array}{l}1,11831^{*} \\
, 34220 \\
, 41146 \\
\end{array}$ & $\begin{array}{l}10471 \\
, 13046 \\
, 18894 \\
\end{array}$ & $\begin{array}{l}, 000 \\
, 078 \\
, 193 \\
\end{array}$ \\
\hline & Olumsuz & $\begin{array}{l}\text { Kararsız } \\
\text { Fikri yok }\end{array}$ & $\begin{array}{l}-, 77610^{*} \\
-, 70684^{*}\end{array}$ & $\begin{array}{l}12230 \\
, 18340 \\
\end{array}$ & $\begin{array}{l}, 000 \\
, 002 \\
\end{array}$ \\
\hline & Kararsız & Fikri yok &, 06926 & ,19923 & ,989 \\
\hline \multirow{3}{*}{$\begin{array}{l}\text { Sığınmacıların Olumlu } \\
\text { Etkilerinin Olduğunu } \\
\text { Düşünme }\end{array}$} & Olumlu & $\begin{array}{l}\text { Olumsuz } \\
\text { Kararsız } \\
\text { Fikri yok }\end{array}$ & $\begin{array}{l}79386^{*} \\
35725 \\
, 36762\end{array}$ & $\begin{array}{l}11961 \\
, 14903 \\
, 21583\end{array}$ & $\begin{array}{l}, 000 \\
, 126 \\
, 408\end{array}$ \\
\hline & Olumsuz & $\begin{array}{l}\text { Kararsız } \\
\text { Fikri yok }\end{array}$ & $\begin{array}{l}-, 43661^{*} \\
-, 42624\end{array}$ & $\begin{array}{l}\text { 13971 } \\
\text { 20951 }\end{array}$ & $\begin{array}{l}, 022 \\
, 249\end{array}$ \\
\hline & Kararsız & Fikri yok & 01037 & ,22758 & 1,000 \\
\hline
\end{tabular}

Sığınmacılara kapıların açılmasına olumlu bakan katılımcıların ekonomiyle ilgili kaygıları diğer tüm katılımcılardan daha düşüktür. Olumsuz bakan katılımcıların ekonomik konularla ilgili kaygı düzeyleri kararsız olanlar ve bu konuda fikri olmayanlardan daha yüksektir. Bu sonuçlar, genel değerlendirmede verilen cevaplarla Likert tipi ifadelere verilen cevapların tutarlı olduğunun da bir göstergesidir. Bunun yanı sıra, sığınmacılara ilişkin genel tutumları etkileyen en önemli konunun ekonomide yaşanacak değişimler olduğu da görülmektedir. Ekonomik konularda kaygılı olan katılımcılar, aynı zamanda sığınmacılara karşı genel olarak negatif tutumlara sahiptir.

Sığınmacılara olumlu bakan katılımcıların pozitif ayrımcılık rahatsızlığı diğer tüm gruplardan düşüktür. Sığınmacılara olumsuz yaklaşan katılımcılar ise, kararsız yaklaşan katılımcılardan daha çok pozitif ayrımcılık rahatsızlığı hissetmektedir. Bu bulgular da genel tutumların büyük ölçüde ekonomiyle ilgili endişelerden kaynaklandığına işaret etmektedir.

Sığınmacılara genel olarak olumlu yaklaşanlar, olumsuz yaklaşanlara göre bir arada yaşamaya daha çok isteklidir. Olumlu tutumları birlikte yaşama ve sığınmacılara yardımcı olma konusunda daha ılımlı olmaları sonucunu doğurmaktadır. Bu bakımdan, olumlu tutumların olumlu davranışları geliştirdiği söylenebilir. Bunun yanı sıra olumsuz tutuma sahip katılımcılar kararsız 
ve fikri olmayan katılımcılara göre sığınmacılarla bir arada yaşama konusunda daha isteksizdir. Bu sebeple, birlikte yaşama ve sığınmacılara destek olma konusunda en katı olan grubun olumsuz tutuma sahip katılımcılar olduğu söylenebilir. Ayrıca sığınmacılar konusunda genel olarak olumlu tutuma sahip olanlar, sığınmacıların pozitif etkilerinin olduğuna da olumsuz tutuma sahip katılımcılardan daha çok inanmaktadırlar.

Yakın çevresinde ikamet eden sığınmacı olanlar, olmayanlar ve bu konuda bilgisi olmayanların sığınmacılara ilişkin algılarının farklılaşıp farklılaşmadığı tek yönlü varyans analizi ile test edilmiş anlamlı farklıık tespit edilememiştir.

Farklı illerde ikamet eden katılımcıların sığınmacılara ilişkin algılarının farklılaşıp farklılaşmadığı tek yönlü varyans analizi ile test edilmiştir. Tüm faktörler açısından anlamlı fark olduğu tespit edilmiştir. Farkın yönünü gösteren Scheffe testi sonuçları aşağıdaki tabloda özetlenmektedir.

Tablo 6: illere Göre Farklılıkları Gösteren Scheffe Testi

\begin{tabular}{|c|c|c|c|c|c|}
\hline Değişken & I & J & Ortalama Farkı & Standart Hata & Anlamlılık \\
\hline \multirow[t]{2}{*}{ Ekonomik Kaygılar } & Mardin & $\begin{array}{l}\text { İstanbul } \\
\text { Tokat }\end{array}$ & $\begin{array}{l}-, 41481^{*} \\
, 362298^{*}\end{array}$ & $\begin{array}{l}10652 \\
, 10754\end{array}$ & $\begin{array}{l}\text {,001 } \\
, 004\end{array}$ \\
\hline & İstanbul & Tokat & ,77780* & 10754 & 000 \\
\hline \multirow{2}{*}{$\begin{array}{l}\text { Pozitif Ayrımcılık Ra- } \\
\text { hatsızlığı ve Hoşnut- } \\
\text { suzluk }\end{array}$} & Mardin & $\begin{array}{l}\text { İstanbul } \\
\text { Tokat }\end{array}$ & $\begin{array}{l}-, 35354^{*} \\
, 26882^{*}\end{array}$ & $\begin{array}{l}10037 \\
10133\end{array}$ & $\begin{array}{l}, 002 \\
, 031\end{array}$ \\
\hline & İstanbul & Tokat & $62235^{*}$ & 10133 & ,000 \\
\hline \multirow{2}{*}{$\begin{array}{l}\text { Sığınmacılarla Birlikte } \\
\text { Yaşamayı Onaylama }\end{array}$} & Mardin & $\begin{array}{l}\text { İstanbul } \\
\text { Tokat }\end{array}$ & $\begin{array}{l}, 70926^{*} \\
-, 12301 \\
\end{array}$ & $\begin{array}{l}11511 \\
, 11621 \\
\end{array}$ & $\begin{array}{l}, 000 \\
, 572 \\
\end{array}$ \\
\hline & İstanbul & Tokat &,$- 83226^{*}$ & ,11621 &, 000 \\
\hline \multirow{2}{*}{$\begin{array}{l}\text { Sığınmacıların Olumlu } \\
\text { Etkilerinin Olduğunu } \\
\text { Düşünme }\end{array}$} & Mardin & $\begin{array}{l}\text { İstanbul } \\
\text { Tokat }\end{array}$ & $\begin{array}{l}07407 \\
-, 31197\end{array}$ & $\begin{array}{l}12848 \\
, 12971\end{array}$ & $\begin{array}{l}847 \\
, 057\end{array}$ \\
\hline & İstanbul & Tokat &,$- 38604^{*}$ & 12971 & 013 \\
\hline
\end{tabular}

Scheffe tablosu incelendiğinde, sığınmacılara ilişkin ekonomik kaygısı en yüksek grubun İstanbul'daki katılımcılar olduğu, onları Mardinli katılımcıların izlediği, ekonomik kaygısı en düşük grubun ise Tokat'taki katılımcılar olduğu görülmektedir. Benzer şekilde sığınmacılara uygulanan pozitif ayrımcılıktan en çok rahatsız olan ve en hoşnutsuz olan grup İstanbul'daki katılımcılardır. Yine onları Mardinli katılımcılar izlemektedir. Tokatı katılımcıların hoşnutsuzluk düzeyleri de diğerlerinden düşüktür. Bu bulgular birlikte değerlendirildiğinde, esasında sığınmacılara ilişkin olumsuz tutumların bir büyükşehir refleksi olduğu düşünülebilir. Büyükşehir insanının ekonomik anlamda daha büyük sorunlarla mücadele ettiği düşünülürse bu refleks normal karşılanabilir. Zaten kıt olduğunu düşündüğü kaynakların ülke vatandaşı olmayan yabancı gruplarla paylaşılacak olması büyükşehir insanını korkutmakta ve bu korku yabancı gruplara karşı tepkili olması sonucunu doğurmaktadır.

Sığınmacılara birlikte yaşama fikri, Mardinli katılımcılara İstanbullu katılımcılardan daha sıcak gelmektedir. Tokatlı katılımcılar da birlikte yaşamaya İstanbullulardan daha ılımlı yaklaşmaktadır. Bu bulgu da büyükşehirli olmakla ilgili bir durumdur. İstanbul'da ikamet edenler, kendileri başka şehirlerden İstanbul'a göç etmiş olsalar dahi İstanbul'a her yeni geleni, adeta şehrin sırtına yüklenmiş bir yük olarak görmektedir. Bu yeni göç, özellikle ülke dışından gerçekleşen bir göç ise büyükşehir insanının daha olumsuz bir tutum sergilemesi mümkündür. Oysa küçük şehirlerde geçim sıkıntısı ve diğer ekonomik kaygılar büyük şehirlerdeki kadar baskın değildir. Bunun yanı sıra, insanlar arasındaki iletişim ve yardımlaşma da daha yaygın olduğu için ekonomik 
problemler kendi içinde de çözümlenebilmektedir. Nitekim araştırma örneklemini oluşturan üç ilden en küçüğü olan Tokat'ta katılımcılar sığınmacıların şehre ekonomik ve kültürel katkılarının olduğunu dahi düşünmektedir. Bu durumda Tokat'ın göç alma geçmişinin de etkisi olabileceği düşünülmektedir. Nitekim Tokat, Suriyeli sığınmacılardan önce Bulgaristan, Afganistan ve Irak'tan gelen sığınmacılara da ev sahipliği yapmış; şehrin sakinleri aynı yerleşim alanlarında o gruplarla birlikte uzun yıllar birlikte yaşamıştır.

\section{Sonuç ve Öneriler}

Suriyeli sığınmacı nüfusunun oldukça yoğun olduğu üç ilde gerçekleştirilen bu araştırmada; bu şehirlerin sakinlerinin sığınmacılarla ilgili algıları belirlenmeye çalışılmış ve bu algıların sığınmacılara ilişkin politikalarda bir pazarlama sorununa işaret edip etmediği tartışmaya açılmıştır.

Araştırmanın en önemli sonuçlarından biri, katılımcıların Suriyeli sığınmacılara ilişkin genel olarak olumsuz tutumlara sahip olmasalar da kaygılı oldukları sonucudur. Bu kaygıların en önemli gerekçesi ise, ekonominin genel durumu ve bireylerin ekonomik durumlarındaki değişimlerdir. Katılımcılar kaynakları ülke vatandaşı olmayan yabancı gruplarla paylaşmanın, geçim sıkıntısına sebep olacağına inanmaktadır. Bunun yanı sıra, ekonomik anlamdaki en önemli kaygılardan biri, sığınmacıların düşük ücretlerle çalışmaya razı olmaları sebebiyle yaşanacak istihdam problemidir. Katılımcılar, düşük ücretlerle çalışan sığınmacıları yerli halkın iş bulamamasının müsebbibi olarak görmektedirler. Oysa bu durum sığınmacılara uygulanan sömürünün bir göstergesi, aynı zamanda sığınmacıların verdikleri yaşam mücadelesinin de bir ispatıdır. Mevcut kurulu düzenleri bir iç savaş neticesinde bozulan ve yeni bir ülkede, yeni bir düzen kurup hayatta kalmaya çalışan sığınmacılar, yerli halkın çalışmaya razı olmadığı ücretlerle istihdam ediliyor ise sığınmacılardan önce işverenlerin mesuliyeti sorgulanmalıdır. Oysa hem kamuoyunda, hem de medyada işverenlerin ücret politikaları hiç tartışmaya açılmamakta, düşük ücretlerle çalışmaya razı olan sığınmacılar günah keçisi olmaktadır. Bunun yanı sıra, çalışmadan sosyal yardımlarla ve daha da ötesi dilenerek geçinmeye çalışan sığınmacılar da tembellik ve hazıra konuyor olmakla eleştirilmektedir.

Katılımcılar sığınmacılara uygulandığını düşündükleri pozitif ayrımcılıktan şikâyetçidir. Kendi muhtaçlarımızın ihtiyaçları görmezden gelinerek, sosyal yardımların sığınmacılara yağdırıldığını düşünmekte ve bu yardımların onların ülkelerine dönme ihtimallerini ortadan kaldırdığına ve onları tembelleştirdiğine inanmaktadırlar. Oysa bu düşünceler de gerçeği yansıtmamaktadır. Sosyal yardımlardan ancak kayıtlı olan sığınmacılar faydalanabilmektedir. Yerleşik sığınmacıların pek çoğunun ise kabul süreçleri devam etmektedir. Dolayısıyla bir ailenin fertlerinin tamamı sosyal yardımlardan faydalanamamakta, faydalanan bireyin bakmakla yükümlü olduğu aile ferdi sayısı çok olduğu için sosyal yardımlar temel ihtiyaçlarını karşılamalarına yetmemektedir.

Araştırmanın önemli bulgularından biri, medyada tutundurulan sığınmacılarla ilgili sorunların, günlük hayatta yaşanan sorunlardan farklı olduğu bulgusudur. Medyada münferit olaylardan hareketle sığınmacılarla ilgili temel sorunların toplumsal düzene ilişkin tehditler ve güvenlik sorunu olduğu tutundurulmaktadır. Oysa halkın gündelik hayatta yaşadığı sorunlar büyük ölçüde istihdamdaki azalma, kiralarda artış, sosyal yardımların azalması gibi ekonomik kökenli sorunlardır. Esasında yerli halk başka bir ülkenin vatandaşlarının yaratacağı güvenlik sorunundan değil, artan nüfus nedeniyle yaratacakları ekonomik sorunlardan mustariptir. Bu kaygı ayrıca büyük şehirlerde daha yoğundur. Daha düşük nüfuslu şehirlerde sığınmacılar büyük bir ekonomik tehdit olarak algılanmamaktadır. 
Katılımcıların sığınmacılara ilişkin algıları ve tutumları vicdanları ve akılları arasında kararsız kalmıştır. Katılımcılar ölümden kaçan, zor durumda olan, mağdur olan kişilere; komşu bir ülkenin vatandaşı ya da bizimle aynı dinin mensubu olmasalar da kucak açılması gerektiğini düşünmekle birlikte, bu merhametin istismar edilmesinden de endişelidirler. Vicdan ve akıl kıskacında kalmalarına sebep olan düşünce "Evet ölümden kurtulmalı, hayatta kalmalılar, ama benim ekmeğimi bölüşerek mi?” düşüncesidir. İhtiyaçlarını eskisi kadar rahat karşılayamama korkusu, sığınmacılara ilişkin genel tutumların da belirleyicisi olmaktadır.

Katılımcıların açık uçlu sorulara verdikleri cevaplar da ilginç bulgular ortaya koymaktadır. Katılımcılar sığınmacılara yönelik politikaların onların ülkelerine dönme ihtimallerini ortadan kaldırdığını, bu nüfus yükünün uzun süre çekilemeyeceğini, Türkiye'nin uyguladığı politikaların ülkelerindeki sorunu çözme yönünde olmadığını, hukuki durumlarının belirsiz olduğunu, artık misafirliklerinin çıktığını, bu belirsizlikler konusunda bilgilendirilmediklerini düşünmektedirler. Bu belirsizlik, katılımcılar tarafından sonunda vatandaşlık hakkının verileceği şeklinde yorumlanmaktadır. Vatandaşık hakkının verilmesinin ise ekonomik sorunların yanı sıra kültürel sorunların da hissedilir olmasına yol açacağını düşünmektedirler. Bunun yanı sıra açık uçlu sorularda ülkelerinde kalıp savaşmadıkları için onlara kızgın olduğunu, aynı durum bizim başımıza gelse kimsenin bize kapılarını açmayacağını, sınırların bir an önce kapatılması gerektiğini belirtenler de vardır; ancak bu ötekileştirici tutum örnekleme genellenemez.

Araştırmanın bu temel bulguları esasında, sığınmacılara ilişkin tutumlarda bilgi eksikliğinin önemli rolünün olduğuna işaret etmektedir. Türkiye'nin sığınmacılar konusundaki politikası, geçerli mevzuatı, Suriye'ye yönelik dış politikası hakkında vatandaşların yeterince bilgisi yoktur. Bununla birlikte bu bilgisizlikte kişisel bir sorumluluk da hissetmemektedirler. Genel olarak, sığınmacı kabulüne olumsuz bakmakta, ancak tam olarak rasyonel bir gerekçe sunamamaktadırlar. Bu durum diğer çalışmalarda da dikkati çekmektedir. Örneğin Transatlantik Eğilimler Araştırması'nın (2014) sonuç raporuna göre araştırmanın Türkiyeli katılımcılarının \% 67'si hükümetin göç politikasını desteklememektedir. Katılımcıların \% 77 'si göçmenlerin Türkiye'ye gelmelerinin asıl sebebinin iltica olduğunu düşünmektedir. Üç Türk'ten ikisi (\% 66) daha kısıtlayıcı mülteci politikaları istemektedir. \% 21'i politikalar daha az kısıtlayıcı olsun derken sadece \% 10'u mevcut politikaları doğru bulmaktadır. Katılımcıların \% 77'si mülteciler konusunda endişeli olduğunu belirtmiştir. Yine GMF tarafından yürütülen Türkiye'nin Algıları Araştırması'na (2015) göre Türk kamuoyunun \% 70'i Türkiye'nin öncelikle kendi iç sorunlarıyla ilgilenmesini isterken, sadece \% 20'si Türkiye'nin Orta Doğu, Balkanlar ve Orta Asya'da daha aktif bir rol oynaması gerektiğini düşünmektedir. Yanıt verenlerin \% 51'i mevcut dış politikayı onaylamamaktadır. Özelde bazı başlıklara indirgendiğinde bu oran daha da yükselmektedir. Katılımcıların sadece \% 35'i komşu ülkelere yönelik politikaları onaylamaktadır. Göç politikasını onaylayanların oranı ise \% 32'dir. Katılımcılar, Suriyeli sığınmacıların mevzuatımıza göre mülteci olarak tanımlanamayacaklarını bilmemekte, ancak Türkiye'ye gelme sebeplerinin iltica olduğunu düşünmektedirler.

Araştırma sonuçları, sığınmacılara ilişkin algılarda bir pazarlama ve özelde bir tutundurma sorununun var olduğuna işaret etmekte ve diğer araştırmalar da bunu desteklemektedir. Türkiye Cumhuriyeti hükümetinin sürecin başından bu yana takip ettiği politikaların vatandaşlarca anlaşılmadığı açıktır. Katılımcılar misafirliğin süreci, kapsamı ve geleceği konusunda kaygılıdır. Bu sebeple geç kalınmış dahi olsa hükümetin ve devletin Suriye'ye ilişkin dış politikası ve sığınmacıların geleceği ile ilgili planları halka bir an önce doğru iletişim kanalları ile pazarlanmalı ve tutundurulmalıdır. Vatandaşın bu konudaki devlet ve hükümet politikalarına hâkim olması, bu 
politikaları desteklemesini sağlayacak ve ülke sınırları içerinde sığınmacılarla yerleşiklerin barışçıl bir hayat sürmelerini kolaylaştıracaktır. Doğru pazarlanan politikalar yerleşiğin kaygılarını azaltacak, her iki tarafın da kendini güvende hissetmesini sağlayacaktır.

Takip edilen politikaların halk desteğini kazanması her şeyden önce iktidar ve muhalefet partilerinin dış politika ve sığınmacılara karşı izlenecek politikalar konusunda uzlaşıya varmasına bağlıdır. Halkın bu konuda kafasının karışık, aklının ve vicdanının bulanık olmasının en önemli sebebi siyasi partiler arasında uzlaşma sağlanamamış olması ve bu konuda birbirlerini sürekli suçluyor olmalarıdır. Nitekim Devran ve Özcan (2016) çalışmalarında parlamentoda bulunan iktidar ve muhalefet partilerinin Suriye konusuna bakış açıları, sorunu tanımlamaları, çözüm önerileri ve sığınmacılara yaklaşımlarının derin farklııklar arz ettiğine ve Türkiye'nin kendi iç ve ulusal sorunu haline gelen bir konuda ortak politika ve tavır üretilemediğine dikkat çekmektedirler. iktidar ve muhalefet edenlerin bir araya gelip, ortak akıl geliştirerek belirleyeceği politikaların halktan destek alması da kolaylaşacaktır. Bunun yanı sıra bu uzlaşı halkın zihnini de berraklaştıracak, sığınmacılara ilişkin kaygıları büyük ölçüde ortadan kaldırarak meseleye insan hakları temelinde bir bakışı mümkün kılacaktır.

Araştırma sığınmacıların ikamet ettiği üç ille sınırlıdır. Türkiye genelinde toplanan verilerle yürütülecek nicel çalışmaların sonuçları aydınlatacağı düşünülmektedir. Yazında bu konu üzerine yapılan nitel çalışmaların ağırlıkta olduğu görülmektedir. Bunun yanı sıra konu ağırlıklı olarak sosyologların dikkatini çekmiştir. Ancak sığınmacılarla ilgili algı ve tutumlarda ekonomik kaygıların da belirleyici olduğu dikkate alınırsa bu konuda yapılacak multidisipliner nicel araştırmaların yazına çok önemli katkılar sağlayacağı düşünülmektedir. 


\section{Kaynaklar}

Apak, Hıdır (2015), "Suriyeli Göçmenlerin Gelecek Beklentileri: Mardin Örneği”, Birey ve Toplum, Cilt. 5, No.9: $125-141$. Atasü Topçuoğlu, Reyhan (2014), “Hayatı Değiştirmek İçin Yola Çıkanlar-Yola Çıkınca Değişen Hayatlar: Bir Müracaatçı Grubu Olarak Göçmen Çocuklar", Toplum ve Sosyal Hizmet, Cilt. 25, No. 1: 89-107.

Bauman, Zygmunt (2003), Modernlik ve Müphemlik, (çev. İsmail Türkmen), İstanbul: Ayrıntı.

Bauman, Zygmunt (2004), Sosyolojik Düşünmek, (çev. Abdullah Yılmaz), İstanbul: Ayrıntı.

Boz, Dicle (2016), “Dış Göçler Olgusu ve Etkisi: Türkiye-Suriye Üzerine Bir İnceleme”, Sosyoekonomi, Cilt. 24, No. 30: 147-153.

Deniz, Çağlar A.; Hülür, Banu A.; Ekinci, Yusuf (2016), “Göç, Strateji ve Taktik: Suriyeli Sığınmacıların Gündelik Hayat Deneyimleri”, Uluslararası Sosyal Araştırmalar Dergisi, Cilt. 9, No. 42: 1077-1087.

Derrida, J. (2000), “Hostipitality” (çev. Strocker, B.; Morlock, F.), Angelaki, Vol.5, No.3: 3-18.

Devran, Yusuf; Özcan, Ömer Faruk (2016), "Söylemlerin Dilinden Suriye Sorunu", Marmara Iletişim Dergisi, Yıl.2016, No.25: 35-52.

Erder, Sema (2010), "'Düzensiz" Göç, Göçmen Korkusu ve Çelişen Tepkiler”, Türkiye'ye Uluslararası Göç Toplumsal Koşullar-Bireysel Yaşamlar (Ed. Barbara Pusch ve Tomas Wilkoszewski), İstanbul: Kitap Yayınevi, 41-55.

Eroğlu, Deniz (2015), “Ulusal Güvenlik Kaygılarından Mali Külfet Söylemine: Türkiye'nin Yeni Sığınma Politikaları”, CBÜ Sosyal Bilimler Dergisi, Cilt.13, No.2: 209-226.

Faist, T. (1997), "The Crucial Meso-Level" International Migration, Immobility and Development: Multidisciplinary Perspectives, (Ed. Hammar, T.; Brochmann, G.; Tamas, K.; Faist, T.) Berg: Oxford,187-217.

GMF (2014), Transatlantik Eğilimler Araştırması, Ankara.

GMF (2015), Türkiye'nin Algıları Araştırması, Ankara.

Güney, Ülkü; Konak, Nahide (2016a), "Bolu’da Suriyeli ve Irakı Sığınmacılar Vatandaşlık ve Kaynak Dağılımı Temelinde Öteki Algısı”, Marmara Üniversitesi Siyasal Bilimler Dergisi, Cilt.4, No.2: 113-133.

Güney, Ülkü; Konak, Nahide (2016b), “Bolu'da Suriyeli ve Iraklı Sığınmacılar: Milliyetçilik, Erillik ve Vatandaşlık Temelinde Öteki Algısı”, Alternatif Politika, Cilt.8, No.3: 505-535.

Işıklı, Şevki (2015), “ilticanın Yapısökümcü Felsefesi: Konuksevermezlik Sorunu”, Marmara Iletişim Dergisi, No.24: 5575.

Kahraman, Fatih; Kahya Nizam, Özlem (2016), “Mültecilik Hallerini Mekan Üzerinden Okumak: Gaziantep Örneğinde Türkiyelilerin Gözünden Suriyeli Kent Mültecileri”, Uluslararası Sosyal Araştırmalar Dergisi, Cilt.9, No.44: 808-825.

Kant, I. (1960), Ebedi Barış Üzerine Felsefi Deneme (çev. Abadan, Y.; Meray, S.), Ankara: AÜ SBF Yayınları.

Kara, Ömer Tuğrul; Yiğit, Ali; Ağırman, Feyzullah (2016), "The Study of The Perceptions of The Students Studying in The Department of Turkish Teaching in Çukurova University About The Term "Syrian Refugee"”, Journal of Theory and Practice in Education, Vol.12, No.4: 945-961.

Kaya, Mahmut (2015), “Komşuda Misafirlik: Suriyeli Sığınmacılarca Kurulmuş Mülteci Derneklerinin Perspektifinden Türkiye'de Yaşamak", The Journal of Academic Social Science Studies, No.39: 263-279.

Kaypak, Şafak; Bimay, Muzaffer (2016), "Suriye Savaşı Nedeniyle Yaşanan Göçün Ekonomik ve Sosyo-Kültürel Etkileri: Batman Örneği”, Batman Üniversitesi Yaşam Bilimleri Dergisi, Cilt.6, No.1: 84-110.

Kömürcü, Yeliz; Özsoy, Rabia; Çobanoğlu, Arzu (2011), "Kadın Sığınmacılar: Uluslararası Göçün Sessiz Tanıkları”, içinde Onlar Bizim Hemşehrimiz Uluslararası Göç ve Hizmetlerin Kültürlerarası Açılımı (Ed. Esen, Erol; Yazıcı, Zeliha), Ankara: Siyasal Kitabevi,111-128.

Mamuk, Rojjin; Şahin Hotun, Nevin (2016), “isstanbul’da Düzensiz Göçmen Olarak Yaşayan Kadınların Sosyodemografik Özellikleri ve Yaşadıkları Sorunlar", Journal of Human Sciences, Cilt.13, No.3: 5174-5188.

Man, Fuat (2016), “"Günah Keçileri” ya da "Olağan Şüpheliler” Olarak Suriyeliler”, Çalışma ve Toplum, Yıl.2016, No.3: 1147-1170.

Noll, G. (2003), "Risky Games? A Theoretical Approach to Burden-Sharing in the Asylum Field", Journal of Refugee Studies, Yıl.16, No.3: 236-252.

Oğuz, Hatice Şule (2015), "Kültürlerarası Karşılaşmaların Uzak İhtimali: Sığınmacılık Deneyiminde Gaziantep Örneği", Tesam Akademi Dergisi, Cilt. 2, No.2: 127-165.

Özekmekçi, M. İ. (2010), “Tehdit Sınırını Geçemeyen Göçmen”, Hayat Sağlık Dergisi, No. 2: 44-48. 


\section{Eskişehir Osmangazi Üniversitesi iiBF Dergisi}

Öztürk, N. Ö. (2015), Mültecinin Hukuki Statüsünün Belirlenmesi, Ankara: Seçkin.

Reçber, Sercan (2014), "Hayatın Yok Yerindekiler: Mülteciler ve Sığınmacılar”, Vı. Sosyal Insan Hakları Ulusal Sempozyumu Bildiriler Kitabı, Anadolu Üniversitesi IïBF ÇEKO Bölümü, 13-14 Kasım 2014, Eskişehir, 247-268.

Şanlıöz, Selma Aybüke (2016), “Dış Göç Olgusunun Düzensiz Göç Gerçeği: Karşılaşılan Etkilere Ekonomik ve Sosyolojik Çözüm Önerileri”, Sosyoekonomi, Cilt. 24, No.30: 139-145.

Tarman, Bülent; Gürel, Davut (2016), "Awareness of Social Studies Teacher Candidates on Refugees in Turkey", The Journal of Social Studies Research, Article in Press.

Tümtaş, Mim Sertaç; Ergun, Cem (2016), “Göçün Toplumsal ve Mekansal Yapı Üzerindeki Etkileri”, Süleyman Demirel Üniversitesi Iktisadi ve Idari Bilimler Fakültesi Dergisi, Cilt.21, No.4: 1347-1359.

Ünal, Serdar (2014), "Türkiye'nin Beklenmedik Konukları: “Öteki” Bağlamında Yabancı Göçmen ve Mülteci Deneyimi”, Journal of World of Turks, Vol.6, No.3: 65-89.

Yıldız, Ayselin; Uzgören, Elif (2016), "Limits to Temporary Protection: Non-Camp Syrian Refugees in İzmir, Turkey”, Southeast European and Black Sea Studies, Cilt.16, No.2: 195-211.

Yıldız, Keriman; Ünlü, Ümmühan; Sezer, Metin (2014), “Mülteci-Sı̆̆ınmacı Cinnetleri ve Toplum “Her İnsanın Huzur İçinde, Kendi Evinde, Sevdiği İnsanların İçinde ve Vatanında Ölme Hakkı Vardır!"”", KMÜ Sosyal ve Ekonomik Araştırmalar Dergisi, No.16 (Özel Sayı): 42-50. 